\title{
De symbiose tussen plattelandsgebieden en stedelijke centra in Vlaanderen
}

Citation for published version (APA):

Vanhaverbeke, W. P. M. (1999). De symbiose tussen plattelandsgebieden en stedelijke centra in Vlaanderen. NIBOR, Netherlands Institute of Business Organization and Strategy Research. NIBOR Research Memorandum No. 04 https://doi.org/10.26481/umanib.1999004

Document status and date:

Published: 01/01/1999

DOI:

10.26481/umanib.1999004

Document Version:

Publisher's PDF, also known as Version of record

\section{Please check the document version of this publication:}

- A submitted manuscript is the version of the article upon submission and before peer-review. There can be important differences between the submitted version and the official published version of record.

People interested in the research are advised to contact the author for the final version of the publication, or visit the DOI to the publisher's website.

- The final author version and the galley proof are versions of the publication after peer review.

- The final published version features the final layout of the paper including the volume, issue and page numbers.

Link to publication

\footnotetext{
General rights rights.

- You may freely distribute the URL identifying the publication in the public portal. please follow below link for the End User Agreement:

www.umlib.nl/taverne-license

Take down policy

If you believe that this document breaches copyright please contact us at:

repository@maastrichtuniversity.nl

providing details and we will investigate your claim.
}

Copyright and moral rights for the publications made accessible in the public portal are retained by the authors and/or other copyright owners and it is a condition of accessing publications that users recognise and abide by the legal requirements associated with these

- Users may download and print one copy of any publication from the public portal for the purpose of private study or research.

- You may not further distribute the material or use it for any profit-making activity or commercial gain

If the publication is distributed under the terms of Article $25 \mathrm{fa}$ of the Dutch Copyright Act, indicated by the "Taverne" license above, 


\title{
De symbiose tussen plattelandsgebieden en stedelijke centra in Vlaanderen
}

\author{
Dr. Wim Vanhaverbeke \\ NIBOR - Universiteit Maastricht \\ Postbus 616 \\ 6200 MD Maastricht \\ Nederland \\ E-mail: w.vanhaverbeke@mw.unimaas.nl
}

\begin{abstract}
:
In Vlaanderen liggen alle plattelandsgebieden op relatief korte afstanden van stedelijke centra. Vaak zijn de afstanden naar het werk en naar bepaalde nutsvoorzieningen - net zoals in Nederland trouwens - niet groter dan voor inwoners van stedelijke gebieden. De economische interacties tussen stedelijke centra en aangrenzende plattelandsgebieden zijn zo intens dat een ontkoppeling van stedelijke centra en open ruimtes waarbij economische activiteiten vooral in de stedelijke centra geconcentreerd moeten worden de realiteit geweld aandoet. We spreken liever van plattelandsregio's als flankerende gebieden: Ze flankeren aan de stedelijke gebieden en de economische relaties tussen beide types van gebieden creëert wederzijdse afhankelijkheid. De economische interacties met stedelijke centra brengen met zich mee dat plattelandsgebieden helemaal niet kunnen vergeleken worden met perifeer gelegen en moeilijk bereikbare rurale regio's elders in Europa, zoals in Schotland en delen van Frankrijk, Italië of Spanje. We proberen dit te verduidelijken aan de hand van pendelgegevens en input-output tabellen.
\end{abstract}




\section{Inleiding}

In deze bijdrage wordt nagegaan wat de economische interacties zijn tussen de stedelijke gebieden en de plattelandsregio's in Vlaanderen. Naast de verschillende socio-economische, landschappelijke en culturele karakteristieken van de plattelandsgebieden die in de andere bijdragen beschreven zijn, is het ook belangrijk om na te gaan wat de economische relaties zijn tussen plattelandsregio's en (nabijgelegen) stedelijke centra.

Omdat er relatief weinig netwerkgegevens bestaan die de relaties weergegeven tussen de verschillende sub-regio's in Vlaanderen zullen we vooral met pendelgegevens en input-output tabellen werken. Uit de analyse zal blijken dat de Vlaamse plattelandsgebieden eigenlijk "flankerende" gebieden zijn ten opzichte van de (nabijgelegen) stedelijke kerngebieden ${ }^{1}$. De economische ontwikkeling van flankerende plattelandregio's hangt af van de vitaliteit van de economische kerngebieden. Maar tezelfdertijd hebben de verstedelijkte economische kerngebieden baat bij het benutten van de specifieke kwaliteiten en potenties van de flankerende plattelandsgebieden. In dichtbevolkte en verstedelijkte gebieden zoals Vlaanderen maken plattelandsregio's integraal deel uit van het economisch leven: de relatief sterke economische prestaties van de Vlaamse plattelandsgebieden zijn onder meer het gevolg van de intense economische interacties met de nabijgelegen stedelijke gebieden. Omgekeerd profiteren stedelijke centra van de aanwezigheid van flankerende plattelandsgebieden: dit is niet alleen zo voor het betrekken van landbouw- of agro-business producten of de mogelijkheden tot toerisme en recreatie, maar ook voor het aantrekken van het arbeidspotentieel, het aanwenden van ruimte die vaak niet langer beschikbaar of onbetaalbaar is in een verstedelijkt gebied en het organiseren van economische activiteiten waarbij het woon- en leefklimaat voor hooggeschoold personeel belangrijk zijn (hoogwaardige dienstverlening, high-tech bedrijven, enz..).

Er bestaat een economische symbiose tussen plattelandgebieden en stedelijke kerngebieden. Dit heeft een tweetal gevolgen. Ten eerste zijn er intense economische interacties tussen beide gebiedstypes waardoor het plattelandsbeleid in zijn samenhang met stedelijke centra moet bekeken worden. Ten tweede steunt deze verhouding tussen plattelandsregio's en grotere stedelijke centra op hun economische complementariteit. In deze bijdrage gaan we vooral in op het eerste thema.

De resultaten van deze studie kunnen we als volgt samenvatten. Nabijgelegen stedelijke gebieden spelen een belangrijke rol in de tewerkstelling van plattelandsinwoners. Precies de nabijheid van grote economische centra maakt het mogelijke om te wonen op het platteland en te werken in een stedelijk gebied. Deze economische verweving draagt op wezenlijke wijze bij tot de welvaart en leefbaarheid van plattelandsregio's. Daarnaast valt over de ganse lijn op dat ook kleinstedelijke gebieden in een plattelandsregio's van cruciaal belang zijn voor de economische dynamiek van zo'n regio. Merkwaardig genoeg slagen de inwoners van vier Vlaamse plattelandsregio's er in om de pendeltijden niet significant te laten verschillen van deze van stedelingen alhoewel de gemiddelde pendelafstand een stuk langer is Dit wijst er onder andere op dat de afstanden die pendelaars vanuit het platteland moeten afleggen geen echte barrière betekenen. Bovendien zijn er grote verschillen tussen de vier plattelandsregio's:

Deze term wordt ook gebruikt bij de economische analyse van de Nederlandse plattelandsregio's (Ministerie van Economische Zaken, 1997) 
bepaalde ruimtelijke karakteristieken zoals de verwevenheid van wonen en werken, het aantal economische knooppunten en hun spreiding in het plattelandsgebied, en de ruimtelijkeconomische positie ten opzichte van grootstedelijke gebieden spelen hierin een rol.

Voor de pendelbewegingen van de schoolgaande jeugd zijn de verschillen tussen plattelandsregio's en stedelijke gebieden iets meer uitgesproken dan voor de werkende bevolking, vooral als men bij de pendelgegevens uitgaat van afstanden en een driedeling maakt tussen stedelijke gebieden, overgangsgebieden en agrarische gebieden. Gaat men daarentegen uit van plattelandsregio's zoals de Westhoek, het Hageland, Haspengouw en het Meetjesland en richt men zich op pendeltijden dan verdwijnen de verschillen met de rest van Vlaanderen. Kortom, ook bij de schoolgaande jeugd zijn de pendeltijden niet systematisch langer in plattelandsregio's. Ook hier zijn verschillen merkbaar tussen de vier plattelandsgebieden.

Tenslotte wordt ook aangetoond dat de interactie niet alleen geldt voor de arbeidsmarkt maar ook voor de eigenlijke economische relaties tussen het platteland en de stedelijk gebieden. De relaties worden indirect in kaart gebracht via input-output tabellen.

We gaan eerst na wat de interacties zijn op het vlak van de arbeidsmarkt tussen het stedelijk gebieden en plattelandsgebieden in Vlaanderen. In de derde sectie gaan we in op mogelijke verschillen tussen de stedelijke gebieden en plattelandsregio's wat betreft het woon-werk verkeer en de pendelbewegingen van de schoolgaande jeugd. In de vierde sectie wordt de relatie tussen de leefbaarheid en de bereikbaarheid van de dorpen onder de loep genomen. Tenslotte gaan we na of de economische relaties tussen het platteland en de stedelijke gebieden even intens zijn als die voor de arbeidsmarkt.

\section{Economische interacties tussen plattelandsgebieden en stedelijke centra}

\subsection{Economische interacties: een functie van de tijdsafstand}

De Vlaamse plattelandsgebieden vormen geen open ruimte waar alleen landbouw en toerisme thuishoren. Het platteland laat zich niet alleen karakteriseren door een lage bevolkingsdichtheid, een groot aandeel van de landbouw in de locale economie, lage gemiddelde inkomens, etc... Plattelandsgebieden differentiëren zich ook op basis van hun ruimtelijk-economische inbedding. Sommige plattelandsgebieden liggen dicht bij grote stedelijke centra, andere zoals in het centraal massief in Frankrijk liggen op grote afstand van de dichtstbijzijnde stad van enige omvang.

Deze ruimtelijk economische inbedding speelt een belangrijke rol in de economische ontwikkelingsmogelijkheden van plattelandsregio's. In dichtbevolkte gebieden zoals Vlaanderen en Nederland zijn plattelandsgebieden voor miljoenen mensen bereikbaar binnen één of enkele uren. Dit houdt in dat zij vanuit het perspectief van de bewoners in grote stedelijke centra in aanmerking komen voor bijvoorbeeld daguitstapjes, recreatiemogelijkheden, de aankoop van een tweede woning voor weekendverblijven, etc... Ook voor de plattelandbewoners heeft de nabijheid van grote stedelijke centra zijn voordelen. Stedelijke centra voorzien in een brede waaier goederen en diensten. De nabijheid van autosnelwegen, HST-stations en luchthavens op een paar uur afstand maakt dat plattelandbewoners de leef- en woonkwaliteit van het platteland kunnen koppelen aan heel wat 
voordelen die stedelijke centra met zich meebrengen. Dat is heel anders voor plattelandsgebieden die erg afgelegen liggen.

In Vlaanderen en het grootste deel van Nederland zijn grote stedelijke centra en plattelandsgebieden vaak op slechts een kwartier of een half uur verwijderd van elkaar. Dat schept heel wat bijkomende economische ontwikkelingsmogelijkheden voor deze gebieden omdat dagelijkse verplaatsingen tussen steden en het platteland dan mogelijk worden. Dit laat toe dat men woont op het platteland terwijl men gaat werken of school loopt in stedelijke centra. In de volgende secties gaan we op basis van pendelbewegingen na hoe die interactie tussen het platteland en de stedelijke gebieden in elkaar steekt en wat de gevolgen ervan zijn voor de plattelandsvernieuwing.

\subsection{Pendelbewegingen tussen het platteland en de stedelijke centra}

Voor de analyse van de pendelbewegingen hebben we ons beperkt tot het Vlaams Gewest en het Brussels Hoofdstedelijk Gebied. Het hoofdstedelijk gebied moet in de analyse opgenomen worden omdat het een heel belangrijke attractiepool is voor de Vlaamse pendelaars. De gegevens zijn afkomstig van de Volkstelling in 1991. Het gaat enkel om pendelgegevens over het woon-werk verkeer.

Om het geheel overzichtelijk te houden is gekozen voor twee afbakeningscriteria van de Vlaamse plattelandsgebieden. De eerste is de afbakening zoals die in de bijdrage van Cabus besproken is. We houden drie categorieën over: het agrarisch gebied, het agrarisch overgangsgebied en de stedelijke gebieden. De tweede bestaat uit een sommatie van de pendelgegevens van vier belangrijke plattelandsgebieden in Vlaanderen: de Westhoek, Haspengouw, het Hageland en het Meetjesland ${ }^{2}$.

Tabel 1 geeft de resultaten weer voor de definitie van plattelandsgebieden die naar voren gebracht is in de bijdrage van Cabus. De tabel moet als volgt gelezen worden: de rijen geven de vertrekplaats (of woonplaats) weer, terwijl de kolommen de plaats van bestemming (werkplaats) aanduiden. Het eerste wat opvalt is dat $91 \%$ van de pendelaars die in stedelijke centra wonen ook in stedelijke gebieden gaan werken. Dit ligt in de lijn der verwachtingen gegeven de sterke verstedelijking van Vlaanderen en de belangrijke rol die stedelijke centra vervullen als tewerkstellingspolen. Tewerkstelling in het agrarisch gebied en het overgangsgebied is voor slechts een minderheid van de inwoners in stedelijke gebieden van belang.

Voeg hier tabel 1 in

Dit ligt helemaal anders voor pendelaars die wonen in het agrarisch overgangsgebied: $79 \%$ werkt in stedelijke gebieden, $16 \%$ in het overgangsgebied en slechts $5 \%$ in het landelijk gebied. Voor het agrarisch gebied is de tewerkstelling zowel in stedelijke gebieden als in de overgangszone belangrijker dan in de agrarische gebieden zelf. Uit deze tabel kunnen we besluiten dat de stedelijke gebieden een uiterst belangrijke rol spelen in de tewerkstelling van

2 Alleen intergemeentelijke pendelgegevens zijn gebruikt voor deze analyse. Pendelbewegingen binnen een gemeente kan men als locale tewerkstelling beschouwen. 
inwoners van het platteland en het overgangsgebied. Anderzijds vervult het agrarisch (overgangs)gebied slechts een marginale rol voor de tewerkstelling van stedelingen.

Ook wanneer men de drie gebieden analyseert als plaats van bestemming komt men tot interessante bevindingen: Van alle "pendeljobs" in de stedelijke gebieden wordt $74 \%$ ingevuld door een stedeling, 20\% door een inwoner van het overgangsgebied en $6 \%$ door een plattelandsbewoner. Voor de jobs in het overgangsgebied komen die cijfers dichter bij elkaar te liggen en voor het agrarisch gebied zijn de drie gebieden goed voor elk een derde van de jobs. Hieruit kunnen we besluiten dat in het overgangsgebied en het agrarisch gebied de jobs die ingevuld worden door mensen van buiten de gemeente uit alle drie de gebieden afkomstig zijn.

Gaat men uit van de vier plattelandsgebieden - de Westhoek, Haspengouw, het Hageland en het Meetjesland - dan komt men tot vergelijkbare resultaten.

\section{Voeg hier tabel 2 in}

Ook hier vinden we dezelfde asymmetrie Slechts $2 \%$ van de pendelaars die wonen buiten deze plattelandsgebieden vindt werk in één van deze vier gebieden. Daartegenover gaat twee derden van de pendelaars, die in één van deze plattelandsgebieden wonen, werken buiten de eigen regio. Pendelaars die wonen in één van deze vier plattelandsgebieden zijn goed voor $8 \%$ van de tewerkstelling in de rest van Vlaanderen. Binnen deze plattelandsgebieden wordt één op drie jobs ingenomen door iemand er niet woont.

In tabel 3 zijn verschillende ratio's berekend voor elk van de vier plattelandsgebieden.

\section{Voeg hier tabel 3 in}

De ingaande pendel is veel kleiner dan uitgaande pendel (kolom 1) waardoor de vier plattelandsgebieden een "pendeldeficit" laten optekenen van gemiddeld meer dan de helft van alle pendelbewegingen met de rest van Vlaanderen en het Brussels Hoofdstedelijk gebied (kolom 2). Het belang van de rest van Vlaanderen en Brussel is weergegeven in de $3^{\text {de }}$ en $4^{\text {de }}$ kolom. Vlaanderen en Brussel staan samen in voor gemiddeld 69\% van de jobs van de pendelaars uit de vier Vlaamse plattelandsgebieden. Tezelfdertijd worden $39 \%$ van de "pendeljobs" in de 4 plattelandsgebieden ingenomen door werknemers die wonen buiten deze gebieden.

De Westhoek neemt een ietwat aparte positie binnen de vier plattelandsgebieden: de verhouding tussen ingaande en uitgaande pendel is het grootst, het deficit het kleinst en het gewicht van Vlaanderen en Brussel in de totale uitgaande en ingaande pendel is het kleinste van de vier regio's. Dit wijst er op dat de Westhoek er in slaagt om de eigen tewerkstelling in de regio beter te garanderen dan de andere drie plattelandsgebieden. Dit kan verschillende oorzaken hebben: de Westhoek is relatief groot, heeft zeven economische knooppunten waardoor er ook op locaal niveau jobs aangeboden kunnen worden, en het zuidelijk deel van de Westhoek wordt gekenmerkt door een sterke verwevenheid van wonen en werken. Dit laatste is tevens een uitgesproken kenmerk is van de "endogene groei"-economie in de aangrenzende arrondissementen Kortrijk, Roeselare en Tielt. 
Economische knooppunten - zoals die gedefinieerd zijn door het Ruimtelijk Structuurplan Vlaanderen - spelen binnen een plattelandsregio een cruciale rol voor de economische ontwikkeling ervan. Dit wordt geilllustreerd in figuur 1.

\section{Voeg hier figuur 1 in}

In deze figuur is de pendeltijd vanuit 56 Westhoekdorpen naar het dichtstbijzijnde economische knooppunt berekend, de ene keer met inbegrip van de zeven economische knooppunten in de Westhoek, de andere keer zonder. In het eerste geval is de pendeltijd vrij klein. Vanuit meer dan de helft van de dorpen kan een economisch knooppunt bereikt worden in minder dan 10 minuten. Bijna alle dorpen liggen op minder dan een kwartier van een economisch knooppunt. Wanneer we deze zeven economische knooppunten buiten beschouwing laten verandert het beeld volledig. Geen enkel economisch knooppunt is bereikbaar onder de 10 minuten en slechts 7 dorpen liggen op minder dan een kwartier afstand van het dichtste economisch knooppunt. Het gros van de dorpen moet het stellen met een minimale pendeltijd tussen 15 minuten en een half uur. Tien dorpen liggen op méér dan een half uur rijden van het dichtste economisch knooppunt.

Toegegeven, economische knooppunten in Noord-Frankrijk zouden in de analyse moeten opgenomen worden. Toch zou dit de resultaten slechts marginaal veranderen. Noord-Frankrijk is niet belangrijk voor de Westhoekpendelaars - toch niet in vergelijking met de rest van WestVlaanderen - en de meest dichtgelegen economische centra in Noord-Frankrijk liggen al vlug op meer dan 20 minuten afstand.

\subsection{Besluit}

Plattelandsgebieden in Vlaanderen zijn uitgesproken flankeringsgebieden. Dit wil zeggen dat ze op zo'n korte (tijds)afstand liggen van relatief grote verstedelijkte centra dat ze intense economische relaties ontwikkeld hebben met deze centra. Dit is in deze sectie empirisch getoetst aan de hand van het woon-werkverkeer. Stedelijk centra zijn van kapitaal belang als tewerkstellingspolen voor inwoners van het platteland in Vlaanderen. Stedelijke centra en plattelandsgebieden kan men vanuit economisch standpunt niet los zien van elkaar. Meer nog, men kan ze alleen definiëren in relatie tot elkaar: de economische mogelijkheden van het platteland zijn duidelijk meebepaald door de ruimtelijk-economische positie die ze innemen t.o.v. de stedelijke centra en deze laatste profiteren dan weer van de complementaire economische activiteiten die ontwikkeld worden in de flankerende plattelandsgebieden.

Deze interrelatie wil nog niet zeggen dat lokale tewerkstellingsmogelijkheden in plattelandsgebieden niet belangrijk zijn. Integendeel, voor de dorpen in de Westhoek werd aangetoond dat de economische knooppunten binnen de Westhoek een cruciale rol vervullen om de Westhoek leefbaar te houden.

\section{Verschillen tussen stedelijke gebieden en plattelandsgebieden: een vergelijking op basis van pendelgegevens?}

In de vorige sectie zijn de pendelrelaties tussen de plattelandsgebieden en de stedelijke centra in kaart gebracht. In deze sectie ga we na of het patroon van de werkende en de schoolgaande 
pendelaars in stedelijke gebieden en plattelandsregio's fundamenteel verschilt van elkaar ${ }^{3}$. Gebruiken plattelandsinwoners andere transportmodi? Zijn zij gemiddeld langer onderweg dan stedelingen en is de afstand die ze afleggen ook groter? Het traditioneel beeld dat men heeft van plattelandsregio's is dat men meer met de wagen naar het werk rijdt omwille van het relatief slecht ontwikkeld openbaar vervoer in plattelandsregio's. Verder gaat men uit van de veronderstelling dat pendelaars uit het platteland gemiddeld grotere afstanden moeten afleggen en dus langer onderweg zijn naar hun werk (of school). In deze sectie gaan we na of dit traditioneel beeld aan de werkelijkheid beantwoordt.

\subsection{Pendelgegevens voor de werkende bevolking}

In de volgende tabellen gaan we achtereenvolgens in op de transportmodi, de reisduur en de afstanden die pendelaars afleggen. Er is een onderscheid gemaakt tussen plattelandsregio's en stedelijke gebieden op basis van 4 mogelijke definities van het platteland. De eerste steunt op het onderscheid tussen gebieden die al dan niet in een stadsgewest liggen. De tweede is gebaseerd op de definitie van Cabus waarbij we een onderscheid maken tussen stedelijke gebieden overgangsgebieden en agrarische gebieden. Een derde afbakening steunt op de bevolkingsdichtheid: gebieden met minder dan 230 inwoners per $\mathrm{km}^{2}$ worden als dunbevolkt beschouwd. De laatste definitie gaat uit van vier plattelandsregio's, m.n. de Westhoek, het Hageland, Haspengouw en het Meetjesland.

De volgende tabellen geven de gewogen gemiddelden aan: de weging gebeurt op basis van het aantal pendelaars. De eerste kolom geeft het aantal pendelaars weer die in een bepaald gebied wonen.

\section{Vervoersmodi}

Tabel 4 geeft aan welke vervoersmodi gebruikt worden voor het woon-werk verkeer. ${ }^{4}$

\section{Voeg hier tabel 4 in}

Deze tabel geeft aan dat meer dan de helft van de pendelaars gebruik maakt van de auto. In stedelijke gebieden is dat 52\%, in het overgangsgebied 56\% en in het agrarisch gebied 58\%. Zoals verwacht is het autogebruik hoger in niet stedelijke gebieden. In alle drie de gebieden schommelt het gebruik van de wagen als passagier tussen de $7 \%$ en $8 \%$. De trein wordt het meest gebruikt in het overgangsgebied (5.4\%), gevolgd door het stedelijk gebied $(5.0 \%)$ en het agrarisch gebied $(4.5 \%)$. Het vervoer door de werkgever ligt verhoudingsgewijs lager in stedelijke gebieden dan in het overgangsgebied en het agrarisch gebied. Daarentegen is het gebruik van tram, bus en metro - om evidente redenen natuurlijk - veel groter in het stedelijk gebied. Fietsen en bromfietsen zijn goed voor meer dan $10 \%$ van het woon-werk verkeer: deze transportmiddelen worden vooral relatief veel gebruikt in het overgangsgebied $(12.4 \%)$, gevolgd door het agrarisch gebied $(11.2 \%)$ en het stedelijk gebied $(10.3 \%)$. Een mogelijke verklaring voor deze verdeling is dat men in het stedelijk gebied te dicht woont bij zijn werk

\footnotetext{
3 De pendelgegevens die in deze sectie gebruikt worden bevatten in tegenstelling met de vorige sectie ook intra-gemeentelijke pendelgegevens. Ook hier zijn Vlaanderen en het Brussels Hoofdstedelijk Gebied als referentiegebied genomen.

$4 \quad$ In de bespreking van deze en volgende tabellen beperken we ons tot de plattelandsgebieden zoals die gedefinieerd zijn door Cabus en de 4 Vlaamse plattelandsgebieden.
} 
zodat het traject ook te voet kan gedaan worden, of dat men alternatieven heeft zoals de tram en de metro. In het platteland zijn de afstanden naar het werk al vlug te groot om ze in een redelijke tijd per fiets af te leggen. Pendelaars die uitsluitend te voet naar hun werk gaan vinden we vooral in het stedelijk gebied.

Uit deze gegevens kunnen we concluderen dat pendelaars vooral deze vervoersmodi gebruiken die beschikbaar zijn en hen binnen een redelijk termijn naar hun werk brengen. Het groot aandeel van het autoverkeer in niet stedelijke gebieden is een gegeven dat we verwachtten. Het vervoer door de werkgever zou kunnen beschouwd worden als een compensatie voor het ontbreken van openbaar vervoer in het agrarisch gebied en het overgangsgebied.

Wanneer we kijken naar de 4 plattelandsgebieden dan vallen de grote verschillen op tussen deze landelijke gebieden. Zo scoort de Westhoek lager dan de rest van Vlaanderen wat betreft het autoverkeer terwijl het autogebruik populairder is bij pendelaars in de andere plattelandsgebieden. Meereizen als passagier is populairder in Haspengouw en het Hageland, maar de Westhoek en het Meetjesland komen onder het niveau van het referentiegebied te liggen.

Dezelfde verschillen tussen de plattelandsgebieden vinden we bij het treinverkeer. Het Hageland scoort merkelijk hoger dan het referentiegebied, de andere regio's scoren lager. Een gelijkaardige situatie doet zich voor met betrekking tot motorfietsen en scooters, en fietsers en bromfietsers; voor beide transportmodi scoren Haspengouw en het Hageland lager ten opzichte van het (verstedelijkt) referentiegebied. In de Westhoek en het meetjesland liggen die scores dan weer een stuk hoger.

Alle plattelandsregio's scoren beduidend lager wat betreft het gebruik van bus, tram en metro - hoe kan het ook anders? In plattelandsregio's gaan pendelaars doorgaans minder te voet naar hun werk: de Westhoek vormt hierop een uitzondering. De reden daarvoor is dat de Westhoek profiteert van een sterke verwevenheid van wonen en werken - zoals trouwens in Zuid en Midden West-Vlaanderen ook het geval is: in de Westhoek wonen $19.3 \%$ van de pendelaars op minder dan $3 \mathrm{~km}$ van hun werk. In het referentiegebied is dit $15.2 \%$ en in de drie andere plattelandsregio's ligt dat cijfer nog lager.

Kortom, wat betreft het gebruik van transportmodi voor het woon-werk verkeer zijn duidelijke verschillen waar te nemen tussen de landelijke en de verstedelijkte gebieden. Zoals verwacht scoort het autogebruik (maar ook motorfietsen, bromfietsen en fietsen) hoger in plattelandsregio's. Het openbaar vervoer scoort minder goed dan in verstedelijkte gebieden, wat op basis van de zwakke uitbouw van het openbaar vervoer in plattelandsregio's niet verwonderlijk is. Het vervoer door werkgevers scoort hoger in plattelandsregio's en dit kan zonder meer gezien worden als een compensatie voor het gebrek aan openbaar vervoer.

Verder is er op gewezen dat men de verschillende plattelandsregio's zeker niet over dezelfde kam mag scheren. De onderlinge verschillen zijn vaak even groot als die ten opzichte van de stedelijke gebieden. Sommige van die verschillen zijn te verklaren vanuit de ruimtelijkeconomische positie van het plattelandsgebied (zoals de grote pendelstromen per trein van het Hageland naar Leuven en Brussel) of vanuit de ruimtelijke structurering van de economie (zoals de korte woon-werk afstanden in de Westhoek). 
Tenslotte bestaat er een verschil wat betreft het autogebruik in plattelandsgebieden zoals die gedefinieerd zijn door Cabus en de vier traditionele plattelandsgebieden: de verschillen tussen deze laatste en het referentiegebied zijn minder uitgesproken dan in het geval van de Cabusdefinitie. Dit wijst er weerom op dat kleinstedelijke centra in de plattelandsgebieden een belangrijke rol spelen in de opbouw van een plattelandsregio. In strikt rurale gebieden van een plattelandsgebied - wat ongeveer overeenkomt met de Cabus-definitie van een plattelandsgebied - zijn de afstanden langer en het autogebruik (dus) intenser. Met de kleinstedelijke gebieden erbij kan men geen onderscheid maken tussen de plattelandsregio's en de rest van Vlaanderen (+Brussel).

\section{Reisduur}

Voor de reisduur zijn vier limieten in acht genomen. Ten eerste zijn er de pendelaars die binnen het kwartier ter plaatse zijn. Vervolgens nemen we de pendelbewegingen die minder dan een half uur duren. We verruimen dit verder naar 45 minuten en tenslotte gaan we na hoeveel pendelaars er méér dan een uur over doen. Tabel 5 geeft de resultaten.

\section{Voeg hier tabel 5 in}

Men zou verwachten dat pendelaars vlugger op hun werk zijn in stedelijke gebieden. Uit de tabel blijkt dat dit niet het geval is. Het agrarisch overgangsgebied scoort het best voor reistijden binnen het kwartier. Eenmaal men de grens verlegt naar 30 en 45 minuten doet het agrarisch gebied het iets beter. In de drie types van gebieden heeft één op tien pendelaars meer dan een uur nodig om zijn werkplaats te bereiken. M.a.w., de pendelreistijden op het platteland en in de stedelijke gebieden zijn vergelijkbaar.

Wanneer we de vier plattelandsregio's vergelijken met de rest van Vlaanderen en Brussel dan valt op dat drie van de vier plattelandsregio's kortere pendeltijden laten noteren dan het referentiegebied. De Westhoek neemt hierbij een extreme positie in: $36 \%$ van de pendelaars is binnen het kwartier op zijn werk en $73 \%$ binnen het half uur. Voor het referentiegebied zijn die cijfers respectievelijk $25 \%$ en $60 \%$. Het Hageland vormt een uitzondering: slechts $48 \%$ van de pendelaars is binnen het half uur op hun werk en $20 \%$ doet er méér dan een uur over.

De kortere pendeltijden in plattelandsregio's kunnen ten dele verklaard worden door het arbeidsprofiel van de pendelaars. In plattelandsregio's is de gemiddelde scholingsgraad van de actieve bevolking wat lager dan in stedelijke gebieden. Bij hooggeschoolden is de gemiddelde pendelafstand (en -tijd) groter: dit kan dus een eerste verklaring zijn van de kortere pendeltijden in plattelandsregio's. Ten tweede speelt de ruimtelijke structuur van de locale economie een rol: in de Westhoek zijn de kortere pendeltijden onder andere te wijten aan de verweving van wonen en werken. De uitzonderingspositie van het Hageland dient gezocht te worden in de het feit dat het gebied een woonforenzengebied is van Leuven en Brussel ${ }^{5}$. De drie andere plattelandsgebieden ontsnappen grotendeels aan de invloed van grootstedelijke gebieden.

\section{Afstand}

Het effect van grotere steden is ook weergegeven in tabel 5. Gebieden die in een stadsgewest liggen (o.a. woonforenzen) hebben gemiddeld langere pendeltijden. 
Tabel 6 geeft een overzicht van de verschillen tussen stedelijke gebieden en plattelandsregio's wat betreft de pendelafstanden.

\section{Voeg hier tabel 6 in}

De resultaten zijn in grote lijnen vergelijkbaar met die van de pendeltijden. In stedelijke gebieden leggen $27 \%$ van de pendelaars minder dan $5 \mathrm{~km}$ af. In het overgangsgebied is dat $22 \%$ en in agrarische gebieden slechts $18 \%$ in vergelijking. De kloof tussen stedelijke gebieden en de andere gebieden groeit nog als de limiet op $10 \mathrm{~km}$ vastgesteld wordt. Zowel in het overgangsgebied als in het agrarisch gebied zijn er relatief veel pendelaars die 10 tot $20 \mathrm{~km}$ afleggen waardoor de kloof met de stedelijke gebieden weer kleiner wordt. In stedelijke gebieden zijn er relatief minder pendelaars die meer dan $30 \mathrm{~km}$ afleggen. Het feit dat de gebiedstypes voor de pendelafstanden significant verschillen van elkaar terwijl dit niet het geval is voor de reistijden is op zich een interessant gegeven: het wijst er op dat niet de afstanden als dusdanig maar wel de pendeltijden de relevante variabele zijn. Pendelaars in overgangszones en agrarische gebieden slagen er in om via "aangepaste" vervoersmodi ongeveer even lang onderweg te zijn als hun collegae uit stedelijke gebieden. Afstanden vormen voor het woon-werk verkeer in Vlaamse plattelandsgebieden geen barrière.

Wanneer we uitgaan van de vier Vlaamse plattelandsregio's dan krijgen we een vergelijkbare resultaten met de pendeltijden. Met uitzondering van de Westhoek zijn de pendeltrajecten vanuit plattelandsgebieden langer dan die vanuit het referentiegebied. Vooral het Hageland wordt gekenmerkt door een hoog percentage van lange afstandspendels: $30 \%$ reist meer dan $30 \mathrm{~km}$ terwijl dit in het referentiegebied slechts $13 \%$ is. In de Westhoek woont $29 \%$ pendelaars op minder dan $5 \mathrm{~km}$ van hun werk. In de rest van Vlaanderen en Brussel is dat slechts $25 \%$. De kloof wordt kleiner bij grotere afstanden: bij $20 \mathrm{~km}$ is het cijfer voor de Westhoek vergelijkbaar met dat van het Meetjesland en ligt het iets onder dat van het referentiegebied. De Westhoek is het enige plattelandsgebied dat t.o.v. het referentiegebied een kleiner percentage pendelaars heeft die méér dan $30 \mathrm{~km}$ pendelen.

Uit deze pendelsgegevens kunnen twee belangrijke conclusies gehaald worden. Ten eerste zijn er duidelijk verschillen tussen de vier plattelandsregio's. Een gedifferentieerd beleid dat rekening houdt met de eigenheden van elk van deze regio's is dus wenselijk. Ten tweede is er een onderscheid in de resultaten - net zoals bij de pendeltijden - tussen agrarische gebieden zoals die door Cabus gedefinieerd zijn en de vier Vlaamse plattelandsregio's: Bij de Cabusdefinitie is er een duidelijk verband tussen het plattelandskarakter van een regio en langere pendelafstanden. Bij de vier plattelandsgebieden is het verschil met het referentiegebied alleen voor het Hageland statistisch significant. Dit wijst er op dat de kleinstedelijke gebieden in plattelandsregio's een belangrijke rol spelen in het temperen van de pendelafstanden en tijden.

\subsection{Pendelgegevens voor de schoolgaande bevolking}

Strijker (1996) komt tot de bevinding dat het verschil in pendelafstand tussen stedelijke gebieden en plattelandsregio's kleiner is voor het woon-werk verkeer dan voor de schoolgaande jeugd. Voor het woon-werk verkeer is dat gemiddeld $7.2 \mathrm{~km}$ voor plattelandsbewoners en $6.9 \mathrm{~km}$ voor inwoners in het stedelijk gebied. Voor de pendel naar de 
scholen is dat respectievelijk $7.8 \mathrm{~km}$ en $4.7 \mathrm{~km}$. Een analyse van de Vlaamse pendel van de schoolgaande jeugd verdient daarom de nodige aandacht.

Tabel zeven geeft een overzicht van de vervoersmodi die schoolgaande jongeren gebruiken.

\section{Voeg hier tabel 7 in}

Net zoals voor het woon-werk verkeer zijn er belangrijke verschillen tussen plattelandsgebieden en stedelijke gebieden wat betreft het gebruik van vervoersmodi. De meeste jongeren gaan per fiets of per bromfiets naar school. In het stedelijk en het agrarisch gebied rijdt een vierde van de schoolgaande bevolking per (brom)fiets naar school. In het overgangsgebied is dat $31 \%$. Het relatief lage percentage voor het stedelijk gebied kan verklaard worden door de korte afstanden (zie infra) en de aanwezigheid van het openbaar vervoer. In plattelandsregio's is de afstand vaak te lang om die per fiets af te leggen (zie infra).

In stedelijke gebieden gaan beduidend méér jongeren te voet naar school: in stedelijke gebieden is dat $18 \%$, in het overgangsgebied $11 \%$ en in plattelandsregio's $12 \%$. Méér dan een vijfde van de schoolgaande jeugd wordt met de auto naar school gebracht. In het overgangsen het plattelandsgebied ligt dat percentage iets hoger. De trein wordt iets meer gebruikt in niet-stedelijke gebieden. De bus wordt het meest gebruikt in agrarische gebieden (16\%), gevolgd door de stedelijke gebieden (met inbegrip van tram en metro) (15\%) en het overgangsgebied (13\%). De verschillen met het agrarisch gebied zijn in beide gevallen statistisch significant. Dit wijst op de prominente rol van bussen waar de afstanden vaak te groot zijn om die per fiets af te leggen. Hetzelfde kan gezegd worden van het vervoer dat georganiseerd wordt door de school: het percentage voor het agrarisch gebied ligt significant hoger dan dat voor het overgangsgebied. Op zijn beurt scoort het overgangsgebied beter dan het stedelijk gebied.

Tabel 8 geeft de pendeltijden weer voor de schoolgaande bevolking. In het stedelijk gebied en het overgangsgebied doet $33 \%$ er minder dan 15 minuten over. In het plattelandsgebied is dat slechts $30 \%$. De verschillen vergroten wanneer men de pendels tot een half uur onder de loep neemt: voor het stedelijk gebied is dat $62 \%$, voor het overgangsgebied $60 \%$ en voor het plattelandsgebied 56\%. Deze verschillen zijn statistisch significant in tegenstelling met de pendeltijden voor het woon-werk verkeer. De resultaten bevestigen dus de bevindingen van Strijker voor Nederland.

\section{Voeg hier tabel 8 in}

Men krijgt andere resultaten indien wordt uitgegaan van de vier plattelandsgebieden. Drie van de vier plattelandsregio's hebben in vergelijking met Vlaanderen en Brussel een hoger aandeel jongeren die binnen het kwartier de school bereiken. Alleen het Hageland scoort beduidend lager. Dat tijdsvoordeel van de drie plattelandsvoordeel verdwijnt wanneer de pendeltijd opgetrokken wordt tot een halfuur of 45 minuten. Het is met andere woorden niet zo dat plattelandsgebieden automatisch langere pendeltijden inhouden voor de schoolgaande jeugd. Ook hier dient de verklaring gezocht te worden in het fijnmazig netwerk van lagere en middelbare scholen in kleinstedelijke centra in het plattelandsgebied.

Tabel 9 geeft een overzicht van de afstanden. Hier is een duidelijk verschil te merken tussen de tussen stedelijke gebieden, overgangsgebieden en agrarische gebieden: vooral onder de $5 \mathrm{~km}$ 
en tot $10 \mathrm{~km}$ zijn de verschillen groot ten voordele van het stedelijk gebied. Er zijn ook duidelijke verschillen tussen het overgangsgebied en het agrarisch gebied. Wanneer de bovengrens op $20 \mathrm{~km}$ is worden de verschillen merkelijk kleiner. Agrarische gebieden en overgangsgebieden hebben ook relatief méér jongeren die méér dan $30 \mathrm{~km}$ pendelen.

\section{Voeg hier tabel 9 in}

De vier plattelandsregio's hebben doorgaans langere pendelafstanden, maar de verschillen met de rest van Vlaanderen en Brussel zijn zeker niet groot. Daarenboven bestaan er verschillen tussen de 4 regio's. Zo scoort de Westhoek goed op afstanden tot $10 \mathrm{~km}$ maar éénmaal daarboven leggen jongeren uit de Westhoek heel wat kilometers af om hun school te bereiken. Dat zou onder andere het gevolg kunnen zijn van het feit dat bepaalde technische scholen, hogescholen en universiteiten in verhouding met de rest van Vlaanderen ver af liggen. De andere drie plattelandsgebieden doen het minder goed op afstanden onder de $10 \mathrm{~km}$ maar halen die achterstaand ten dele in als men alle pendels tot $20 \mathrm{~km}$ in beschouwing neemt. Het Hageland heeft ook een vrij groot aandeel van schoolgaande pendelaars die méér dan $30 \mathrm{~km}$ afleggen.

Kortom, wanneer Vlaanderen en het Brussel Hoofdstedelijk Gewest opgesplitst wordt in stedelijke gebieden, overgangsgebieden en agrarische gebieden dan vinden we een duidelijke differentiatie tussen de drie gebiedstypes voor het aantal kilometers die schoolgaande jongeren afleggen. Dat onderscheid tussen stedelijke gebieden en plattelandsgebieden is minder uitgesproken wanneer wordt uitgegaan van de vier Vlaamse plattelandsregio's. De afstanden zijn doorgaans langer dan in de rest van Vlaanderen en Brussel maar de verschillen zijn zeker niet allemaal statistisch significant. Daarenboven zijn er ook verschillen tussen de vier plattelandsgebieden.

\section{Economische groei en bereikbaarheid}

In de twee vorige secties is voor de arbeidsmarkt duidelijk aangetoond dat het plattelandsgebied in Vlaanderen integraal deel uitmaakt van het economisch weefsel samen met de omliggende stedelijke gebieden. Sterker nog: de Vlaamse plattelandsregio's halen een belangrijk deel van hun economische dynamiek hun pendelrelaties met nabijgelegen stedelijke centra. Tezelfdertijd is er reeds een paar keer op gewezen dat kleinstedelijke gebieden in een plattelandsregio een cruciale rol spelen om de locale economie te dynamiseren.

De economisch meest kwetsbare gebieden in een plattelandsregio zijn zonder twijfel de dorpen. Recent onderzoek voor de Westhoek toont aan dat dorpen binnen dezelfde plattelandsregio totaal verschillende (economische) ontwikkelingen kennen (De Roo en Thissen (1997)). Wanneer de bevindingen in de vorige secties kloppen houdt dit in dat de economische groei van de dorpen - en het verschil in groei tussen de dorpen - geen statistisch

significant effect mag ondervinden van de ruimtelijke economische positie van die dorpen binnen het ruimer economisch weefsel. Met andere woorden, dorpen die ver van de economische centra liggen mogen het niet systematisch slechter doen dan zij die dicht bij die centra liggen.

Om op deze vraag een antwoord te krijgen is een variabele ontworpen die we het "jobbereik" van inwoners in verschillende dorpen zouden kunnen noemen. Deze variabele is als volgt 
samengesteld. Vanuit ieder dorp in de Westhoek ${ }^{6}$ zijn met Route Planner 66 de reistijden berekend naar alle economische knooppunten in West-Vlaanderen. Vervolgens zijn deze reistijden gekoppeld aan de pendeltijden van de gemeente waartoe ieder dorp behoort. Tenslotte worden deze gegevens vermenigvuldigd met de tewerkstelling in de verschillende economische knooppunten.

Een voorbeeld kan dit verduidelijken. Booitshoeke ligt op 34 minuten van Brugge. Het dorp behoort tot de gemeente Veurne waar 5.4\% van de pendelaars tussen 30 en 45 minuten onderweg is. In Brugge werkten er in 199652670 werknemers. Het jobbereik voor inwoners in Booitshoeke m.b.t. Brugge is $2844(=0.054 * 52670)$. Deze berekening wordt doorgevoerd voor alle economische knooppunten in West-Vlaanderen en wordt daarna gesommeerd per dorp. Dit eindresultaat wordt als een percentage uitgedrukt van het dorp met het hoogste "jobbereik".

De resultaten zijn weergegeven in de volgende tabel.

\section{Voeg hier tabel 10 in}

Er bestaan grote verschillen tussen de dorpen. Bovekerke heeft het grootste "jobbereik": 32 van de 56 dorpen heeft minder dan de helft van dat bereik en Houtem - de laatst geklasseerde - heeft zelfs minder dan een vierde. De rangschikking tussen 1981 en 1996 is niet wezenlijk veranderd. Wanneer er enkel rekening gehouden wordt met de groei van het "jobbereik" (twee laatste kolommen) is de rangschikking anders en de groei voor de periode 1981-1996 geeft ook een andere classificatie dan de groei voor de periode 1992-1996. De rangschikking van de dorpen in deze laatste twee kolommen hangt sterk af van de dynamiek van de verschillende economische knooppunten: voor de periode 1992-1996 is het duidelijk dat dorpen die sterk op de (zwakgroeiende) economische knooppunten aan de kust afgestemd zijn een lage score hebben.

Deze variabele kunnen we nu samen met andere variabelen gebruiken als een mogelijke verklaring voor de leefbaarheid van de dorpen. In de volgende regressieanalyse meten we de leefbaarheid van een dorp aan de hand van de groei van het aantal gezinnen tussen 1981 en 1992. Dit is een belangrijke variabele omdat de evolutie van het aantal gezinnen een vrij goede indicator is voor de vitaliteit van een dorp.

De resultaten zijn weergegeven in de volgende tabel

6 Omdat deze procedure arbeidintensief is hebben we ons beperkt tot de dorpen in de Westhoek en de economische knooppunten in West-Vlaanderen. Er zijn 56 dorpen opgenomen in de steekproef: het zijn de dorpen waarvoor een aantal socio-economische basisstatistieken beschikbaar zijn (zie De Roo en Thissen (1997)).. 
Tabel 11: Verklaring van de vitaliteit van een dorp in de Westhoek

Onafhankelijke variabele: Gezinsgroei 1981-1996

Constante

Aandeel boerderijen in particulier woningen (\%)

Aandeel particuliere woningen met CV (\%)

Aandeel particuliere woningen zonder klein comfort (\%)

$5 B$-regio (dummy) Jobbereik 1981

Aandeel van actieve bevolking in de totale bevolking Dorpstype: Stagnerende kleine kernen (dummy )

Dorpstype: Stagnerende oude centra (dummy)

Dorpstype: Dynamiek door mogelijkheden (dummy)
Coëfficiënten t-statistiek Significantie-

niveau.

$\begin{array}{rrr}, 478 & 1,655 & , 105 \\ 2,670 \mathrm{E}-03 & 1,161 & , 252 \\ -1,491 \mathrm{E}-03 & -, 697 & , 489 \\ -2,817 \mathrm{E}-03 & -1,396 & , 169 \\ -, 144 & -4,757 & , 000 \\ -8,437 \mathrm{E}-04 & -, 980 & , 332 \\ -, 236 & -, 557 & , 580 \\ -7,178 \mathrm{E}-02 & -1,664 & , 103 \\ -4,121 \mathrm{E}-02 & -, 892 & , 377 \\ , 110 & 2,500 & , 016\end{array}$

Aangepaste- $\mathrm{R}^{2}=0.45$

Voor deze regressieanalyse zijn variabelen gebruikt die beschikbaar waren. De variabelen verklaarden samen 45\% van de totale variantie in de groei van de gezinnen tussen 1981-1996. Onderaan de tabel zijn drie dorpstypes vermeld: Ze geven het verschil in de groei van het aantal gezinnen met het dorpstype "dynamiek door aantrekkelijkheid" weer: dorpen die een dynamiek door mogelijkheden kennen hebben in de periode 1981-1996 een sterkere aanwas van gezinnen gekend. Slechts één andere variabele heeft een statistische significant effect op de groei van het aantal gezinnen, nl. dorpen die deel uitmaken van de 5B-regio groeiden minder snel. Kenmerken van de woningen en de leeftijdstructuur van de bevolking hebben geen significante impact op de groei van het aantal gezinnen. Ook het "jobbereik" heeft geen impact op de onafhankelijke variabele.

Ondanks de grote verschillen in "jobbereik" vinden we geen effect op de leefbaarheid van de dorpen in de Westhoek. Hieruit kunnen we twee mogelijke conclusies halen. Ofwel is de ruimtelijk-economische positionering van de dorpen niet belangrijk voor hun leefbaarheid. Dit resultaat bevestigt onrechtstreeks de theorie van de schaaldifferentiatie waarbij heel wat dorpbewoners in het dorp leven maar in nabijgelegen stedelijke gebieden gaan werken. Ofwel is het "jobbereik" een variabele die de ruimtelijk-economische positie van een dorp ten opzichte van belangrijke economische centra niet nauwkeurig weergeeft. In het eerste geval kunnen we besluiten dat de leefbaarheid van de dorpen niet gehypothekeerd is door het feit dat het ver afgelegen is van economische centra. Dit is dan weer goed te rijmen met de bevindingen dat er sterke economische interacties bestaan tussen het Vlaamse platteland en de steden en met het feit dat er geen significante verschillen bestaan tussen de pendeltijden van plattelandbewoners en stedelingen.

\section{$5 \quad$ Economische interacties tussen stedelijke gebieden en plattelandsgebieden}

Pendelgegevens zijn de enige, publiek beschikbare, relationele gegevens in België die van belang kunnen zijn binnen een economische analyse. Er zijn geen databanken beschikbaar die de economische relaties tussen subregio's in België / Vlaanderen in beeld brengen. Het is 
daarom ook uitgesloten de economische interacties tussen de stedelijke gebieden en plattelandsgebieden in Vlaanderen rechtstreeks te meten ${ }^{7}$.

Er bestaat evenwel een mogelijkheid om deze relatie onrechtstreeks te meten via input-output tabellen. De methode die we hier gebruiken steunt op heel wat vooronderstellingen. De resultaten dienen dus met de nodige omzichtigheid geïnterpreteerd te worden. Niettemin geven ze op zijn minst een indicatie van de grootteorde van deze economische interacties tussen stedelijke gebieden en plattelandsgebieden.

In de analyse gaan we uit van de drie gebieden zoals die door Cabus gedefinieerd zijn: nl. agrarisch gebied, agrarisch overgangsgebied en stedelijke gebieden. We trachten dus te zoeken naar de interacties tussen deze drie gebiedstypes. Voor de input-output tabel werd gekozen voor een Vlaamse input-output tabel die werd aangemaakt door Ludo Peeters van het Limburgs Universitair Centrum te Diepenbeek ${ }^{8}$. Input-output modellen zijn een instrument voor het detecteren van relaties tussen economische sectoren en ze zijn niet bedoeld voor het blootleggen van relaties tussen regio's. Maar omdat regio's een verschillende economische structuur hebben is het mogelijk om mits een aantal vooronderstellingen relaties tussen regio's in beeld te brengen.

Het zwak punt in de analyse is de assumptie dat de drie gebiedstypes goederen / diensten van elkaar betrekken volgens hun aandeel in de desbetreffende sectoren. M.a.w., de drie gebiedstypes zijn indifferent wat betreft de oorsprong en de bestemming van de goederen / diensten. Ze worden betrokken van en geleverd aan de drie gebiedstypes proportioneel aan hun aandeel in de Vlaamse economie. Het is dus een input-output tabel die geen rekening houdt met de afstanden tussen de drie gebiedstypes. Naarmate nabijgelegen gebieden meer in interactie staan met elkaar dan verder afgelegen gebieden is deze assumptie niet realistisch. Gelukkig zijn de drie gebiedstypes sterk verspreid over Vlaanderen zodat de gemiddelde afstand tussen agrarische en stedelijke gebieden relatief klein blijft.

Een tweede zwak punt is dat er alleen gegevens over de bezoldigde tewerkstelling op sectoraal en gemeentelijk niveau bestaan in België. Input-output tabellen zijn daarentegen in waardeeenheden uitgedrukt. De analyse zal dan ook in termen van arbeidseenheden i.p.v. waardeeenheden uitgedrukt worden. Met bezoldigde tewerkstelling wordt het effect van sectoren met relatief veel zelfstandige tewerkstelling onderschat. Omdat in agrarische gebieden ook relatief meer zelfstandige tewerkstelling bestaat zullen de resultaten het belang van agrarische gebieden enigszins onderschatten. Door te werken met arbeidseenheden houdt men verder geen rekening met verschillen in arbeidsproductiviteit tussen de sectoren. Hierdoor zal het belang van de industrie - waar de arbeidsproductiviteit doorgaans een stuk hoger ligt dan in de meeste dienstverlenende sectoren - onderschat worden. Het belang van gebieden met een relatief groot tewerkstellingsaandeel in de industrie, zoals agrarische gebieden, zal hierdoor onderschat worden. Ook het aandeel van de intermediaire vraag binnen de totale vraag zal hierdoor kleiner zijn dan het werkelijk aandeel.

\subsection{Intermediaire vraag}

7 Zo'n databank zou wel kunnen samengesteld worden vanuit de BTW-gegevens waarover het Ministerie van Financiën beschikt.

$8 \quad$ Persoonlijke communicatie: Ludo Peeters, Instituut voor Toegepast Economisch Onderzoek (ITEO), LUC, Diepenbeek. De input-output tabel geeft de situatie in Vlaanderen weer voor het jaar 1995. 
Belangrijk om te weten is in welke mate de agrarische gebieden een beroep doen op economische activiteiten in de andere gebieden en meer bepaald op deze in de stedelijke gebieden. M.a.w, wat is de intermediaire vraag uit de drie gebiedstypes voor de totale productie in het agrarisch gebied ${ }^{9}$. Tabel 12 geeft een overzicht van de verdeling van de intermediaire vraag voor de drie gebiedstypes.

\section{Voeg hier tabel 12 in}

Om de totale economie in het agrarisch gebied - goed voor 93.445 jobs - zijn intermediaire goederen of inputs voor een waarde van 20.138 jobs nodig. Daarvan komt slechts $6.5 \%$ vanuit het agrarisch gebied zelf, $19.5 \%$ komt uit het overgangsgebied en de resterende $73.9 \%$ uit stedelijk gebied. Voor het overgangsgebied zijn die percentages respectievelijk 5.9\%, 18.7\% en 75.4\%. M.a.w., zowel het agrarisch gebied als het overgangsgebied betrekken drie vierde van hun intermediaire vraag uit stedelijke gebieden. Dit wijst er op dat de plattelandseconomie sterk afhankelijk is van de stedelijke economie. Omgekeerd is dit minder het geval: de stedelijke economie betrekt 'slechts' $22 \%$ uit de niet-stedelijke gebieden. Deze asymmetrie is grotendeels het gevolg van de dominantie van de stedelijke gebieden in de Vlaamse economie $^{10}$.

Dezelfde asymmetrie komt naar voor wanneer we de gegevens per kolom bekijken: d.w.z. hoeveel de verschillende gebiedstypes (rijen) aan intermediaire goederen en diensten vragen aan een bepaald gebiedstype (kolom) - zie laatste blok in tabel 12. Voor het agrarisch gebied wordt $70 \%$ van de intermediaire goederen en diensten betrokken vanuit stedelijke gebieden. Dit is zelfs $73 \%$ voor het overgangsgebied. M.a.w., ook hieruit blijkt dat de Vlaamse plattelandseconomie sterk bepaald wordt door de dynamiek van de stedelijke gebieden.

\subsection{Totale vraag en middelen}

De intermediaire vraag geeft slechts een partieel beeld. Ze houdt geen rekening met de finale vraag, de bruto toegevoegde waarde die volledig binnen het gebiedstype in kwestie gerealiseerd wordt, en de import uit zowel het buitenland als Wallonië en het Brussels Hoofdstedelijk Gewest.

Tabel 13 geeft een overzicht van de verdeling van de totale vraag en middelen - uitgedrukt in arbeidseenheden - per gebiedstype.

\section{Voeg hier tabel 13 in}

De drie eerste rijen in tabel 13 geven alle componenten van de totale vraag naar producten en diensten van een gebiedstype weer. Naast de intermediaire vraag is ook de verdeling van de finale vraag in kaart gebracht. De finale vraag - dat zijn bestedingen voor particuliere consumptie, (overheids)investeringen, en export - neemt $82 \%$ van de totale vraag voor zijn rekening. Bij agrarische gebieden ligt dat cijfer iets lager omwille van de relatief grote intermediaire vraag die typisch is voor landbouw en industrie. De finale vraag is uitgesplitst in een binnenlandse component en de export. Omdat voor deze laatste geen gegevens per

$9 \quad$ Dit is de vraag vanuit andere economische sectoren die dan als input binnen deze sectoren zal dienen.

10 Het agrarisch gebied had in 1997 een aandeel in de bezoldigde tewerkstelling van 5.1\%. Het agrarisch overgangsgebied is goed voor $16.6 \%$ en de stedelijke gebieden voor $78.3 \%$. 
gebiedstype bestaan is het getal voor de import vermenigvuldigd met 1,0933 omdat het handelsoverschot $9.33 \%$ van de Belgische import bedroeg ${ }^{11}$. De export neemt een vierde van de finale vraag vanuit het agrarisch gebied voor zijn rekening ${ }^{12}$. Deze sterke exportgerichtheid van de agrarische gebieden is grotendeels het gevolg van de sterke aanwezigheid van de landbouw en de industrie die een meer uitgesproken internationaal karakter hebben dan de meeste dienstverlenende sectoren. In het overgangsgebied valt de vraag vanuit het buitenland terug tot $22 \%$ en in stedelijke gebieden zelfs tot $18 \%$. M.a.w., de economie in het platteland is meer internationaal georiënteerd dan die in de stedelijke gebieden: deze bevinding staat haaks op de visie dat de economie in agrarische gebieden enkel een lokale impact zou hebben.

De binnenlandse vraag wordt uitgesplitst voor de drie gebiedstypes volgens de rijpercentages die weergegeven zijn in tabel 12 . Hieruit blijkt opnieuw hoe belangrijk de vraag vanuit de stedelijke gebieden is voor het platteland. De intermediaire vraag uit stedelijke gebieden is goed voor $16 \%$ en de finale vraag voor $39 \%$ van de totale productie van het agrarisch gebied. Voor het overgangsgebied is dat respectievelijk $15 \%$ en $44 \%$. De vraag vanuit plattelandsgebieden zowel voor producten en diensten uit stedelijke gebieden als voor deze uit de plattelandsgebieden zelf is vrij klein.

Kijken we kolomsgewijs naar de 'middelen' voor de productie in de drie gebiedstypes $\left(3^{\text {de }}\right.$ blok in tabel 13) dan valt op dat de intermediaire productie - dit is de productie die verder gebruikt wordt als input in andere sectoren - rond de $18 \%$ ligt voor de drie gebiedstypes. De stedelijke gebieden nemen daarvan het leeuwendeel voor hun rekening. De rij "bruto toegevoegde waarde" geeft weer welk deel van de productie betaald wordt aan lonen, rentes, winstuitkeringen, enz... De bruto toegevoegde waarde is het laagst in het agrarisch gebied (59\%) en het hoogst in het stedelijk gebied (66\%). Een deel van de middelen wordt ook betrokken uit de import: voor het agrarisch gebied is het aandeel van de import het grootst. Dit relatief groot aandeel van de import wijst net als de export op het internationaal karakter van de plattelandseconomie.

\section{Conclusies}

De economische rol van plattelandsgebieden wordt ondermeer bepaald door hun ruimtelijkeconomische positionering ten opzichte van stedelijke centra. In Vlaanderen en Nederland zijn de plattelandsgebieden doorgaans bereikbaar op minder dan een uur vanuit één of meerdere stedelijke centra. Uit de analyse is gebleken dat Vlaamse plattelandsgebieden eigenlijk "flankerende" gebieden zijn ten opzichte van de (nabijgelegen) stedelijke kerngebieden net zoals dat eerder al is aangetoond voor Nederland (Strijker, 1996; Ministerie van Economische Zaken, 1997). In dichtbevolkte en verstedelijkte gebieden zoals Vlaanderen maken plattelandsregio's integraal deel uit van het economisch leven: de relatief sterke economische prestaties van de Vlaamse plattelandsgebieden zijn onder meer het gevolg van de intense economische interacties met de nabijgelegen stedelijke gebieden. Naarmate plattelandsgebieden 'dichter' gelegen zijn bij stedelijke centra bieden ze ook meer kansen om de voordelen van plattelandsgebieden en stedelijke gebieden te combineren. Het uitgebreid

11 Bron: Ministerie van Economische zaken, Trefpunt Economie, 1999/5B, 16 p. We veronderstellen hierbij dat dit handelsurplus een juiste indicatie geeft voor het handelsurplus van Vlaanderen.

12 Omdat de analyse over Vlaanderen gaat behoren Wallonië en het Brussels Hoofdstedelijk Gewest ook tot het 'buitenland'. 
netwerk van relaties tussen plattelandsgebieden en stedelijke gebieden is slechts één van de vele gevolgen van de groeiende schaaldifferentiatie (zie bijdrage Niek De Roo).

De economische symbiose tussen plattelandgebieden en stedelijke kerngebieden heeft een tweetal gevolgen. Ten eerste zijn er intense economische interacties tussen beide gebiedstypes waardoor het plattelandsbeleid in zijn samenhang met stedelijke centra moet bekeken worden. Ten tweede steunt deze verhouding tussen plattelandsregio's en grotere stedelijke centra op hun economische complementariteit. In deze bijdrage zijn we vooral ingegaan op het eerste thema: stedelijke en landelijke gebieden vormen, althans vanuit ruimtelijkeconomisch standpunt, de twee zijden van dezelfde medaille. Uit de resultaten is gebleken dat de economische dynamiek in de plattelandsgebieden grotendeels afhangt van die in de (nabijgelegen) stedelijke gebieden. Het introduceren van een tweespalt tussen stedelijke gebieden en plattelandsgebieden zoals in het Ruimtelijk Structuurplan Vlaanderen staat haaks op de visie waarbij beide gebiedstypes vanuit een ruimer economisch geheel geduid worden.

De economie in plattelandsgebieden in Vlaanderen is daarenboven niet enkel gericht op lokale of sub-regionale behoeften. In sectie 5 is immers aangetoond dat agrarische gebieden in Vlaanderen méér exportgericht zouden zijn dan stedelijke gebieden. Kortom, de plattelandseconomie is een volwaardig onderdeel van de Vlaamse economie.

Omdat er relatief weinig netwerkgegevens bestaan die de relaties weergegeven tussen de verschillende sub-regio's in Vlaanderen hebben we de analyse enkel kunnen baseren op pendelgegevens en input-output tabellen. Uit de pendelgegevens blijkt onder meer dat de afstanden tussen de woonplaats en de werkplek groter zijn in agrarische regio's dan in stedelijke gebieden. Toch slagen plattelandsbewoners gemiddeld niet langer over het woonwerk verkeer te doen dan hun collegae uit de stedelijke gebieden. Dit is een indirect bewijs dat de afstanden tussen het platteland en de stedelijke centra niet prohibitief groot zijn voor het woon-werk verkeer. Vlaamse plattelandsgebieden kunnen dus zonder meer als 'flankeringsgebieden' gedefinieerd worden.

Uit de pendelgegevens blijkt ook dat men de traditionele plattelandsregio's zoals de Westhoek, Haspengouw, het Hageland en het Meetjesland niet over één kam mag scheren. Vaak zijn de onderlinge verschillen groter dan die met de stedelijke gebieden. Deze verschillen zijn de verklaren vanuit de ruimtelijk-economische positie van het plattelandsgebied of vanuit de eigen kenmerken van de subregionale economie.

Tenslotte is ook aangetoond - althans voor de Westhoek - dat economische knooppunten in plattelandsgebieden een cruciale rol spelen in de economische dynamiek van zo'n gebied: Wanneer alleen economische knooppunten worden voorzien buiten de plattelandsgebieden worden de pendelafstanden te lang waardoor de plattelandseconomie in een neerwaartse spiraal zou terecht komen.

Dorpen zijn de meest kwetsbare elementen in een plattelandsgebied. In sectie 4 is voor de Westhoek aangetoond dat de leefbaarheid van de dorpen niet door de bereikbaarheid vanuit stedelijke tewerkstellingspolen beïnvloed wordt. Andere factoren zoals de kwaliteit van de leef- en woonomgeving spelen wellicht een veel belangrijker rol.

Uit sectie 5 onthouden we dat de plattelandseconomie voor méér dan de helft afhangt van de intermediaire en finale vraag vanuit de Vlaamse stedelijke gebieden. Omgekeerd is de binding 
beduidend kleiner. Deze vaststellingen bevestigen de hypothese dat de Vlaamse plattelandsgebieden 'flankeringsgebieden' zijn, waarvan de economie onafscheidelijk verbonden is met die in de stedelijke gebieden. De plattelandseconomie is daarenboven meer internationaal georiënteerd dan die in de stedelijke gebieden: deze bevinding staat haaks op de visie dat agrarische gebieden enkel een lokale betekenis zouden hebben.

Deze studie is slechts een pilootstudie. Deels door het gebrek aan relevante relationele gegevens dienen de resultaten met de nodige omzichtigheid geïnterpreteerd te worden. Toch is het ook voor kritische lezers duidelijk dat de bevindingen wijzen op de noodzaak om de economie in de plattelandsgebieden en stedelijke gebieden als complementaire delen van een groter economisch geheel te beschouwen. Er bestaat geen stedelijke economie en van een Vlaamse plattelandseconomie kunnen we ook al niet spreken. Daarenboven vormt het buitengebied een klein maar volwaardig onderdeel van de Vlaamse economie met een sterke internationale oriëntatie. De Vlaamse economie inkapselen in stedelijke gebieden zonder rekening te houden met de economie in het buitengebied staats haaks op de resultaten van deze bijdrage. De resultaten van deze studie wijzen er tenslotte ook op dat het vanuit economisch oogpunt zinloos is om een steden- en plattelandsbeleid apart te gaan voeren.

\section{Referenties}

De Roo, Niek en Frans Thissen (1997); Leefbaarheidonderzoek in de plattelandskernen van de Westhoek: Eindrapport, Provincie West-Vlaanderen en Europees Fonds voor Regionale Ontwikkeling, $138 \mathrm{p}$.

Ministerie van Economische Zaken (1997); Ruimte voor Economische Dynamiek: Een verkennende analyse van de ruimtelijk-economische ontwikkelingen tot 2020, Den Haag, 127 p.

Strijker, Dirk (1996); The Dutch countryside: Myths versus facts, Paper for the 48th EAAEseminar on Rural Restructuring within Developed Countries, Dyon-France, March 20-21, 1997, $10 \mathrm{p}$. 
Tabel 1: Relatie tussen stedelijke gebieden en platteland - Definitie Cabus

Aantal
1 Stedelijke gebieden
2 Agrarisch overgangsgebied
3 Agrarisch gebied
Totaal

$\begin{array}{rrrr}1 & 2 & 3 & \text { Totaal } \\ 838995 & 65064 & 13513 & \mathbf{9 1 7 5 7 2} \\ 222545 & 45360 & 12815 & \mathbf{2 8 0 7 2 0} \\ 70617 & 29096 & 13493 & \mathbf{1 1 3 2 0 6} \\ \mathbf{1 1 3 2 1 5 7} & \mathbf{1 3 9 5 2 0} & \mathbf{3 9 8 2 1} & \mathbf{1 3 1 1 4 9 8}\end{array}$

Als \% van pendel uit vertrekplaats

$\begin{array}{lrrrr} & 1 & 2 & 3 & \text { Totaal } \\ & & & & \\ \text { 1 Stedelijke gebieden } & 91.4 \% & 7.1 \% & 1.5 \% & \mathbf{1 0 0 . 0 \%} \\ \text { 2 Agrarisch } & 79.3 \% & 16.2 \% & 4.6 \% & \mathbf{1 0 0 . 0 \%} \\ \quad \text { overgangsgebied } & & & & \\ \text { 3 Agrarisch gebied } & 62.4 \% & 25.7 \% & 11.9 \% & \mathbf{1 0 0 . 0 \%} \\ \quad \text { Totaal } & \mathbf{8 6 . 3} \% & \mathbf{1 0 . 6 \%} & \mathbf{3 . 0} \% & \mathbf{1 0 0 . 0 \%}\end{array}$

Als $\%$ van pendel naar plaats van bestemming

\section{1}
1 Stedelijke gebieden
2 Agrarisch overgangsgebied
3 Agrarisch gebied Totaal

$\begin{array}{rrrr}74.1 \% & 46.6 \% & 33.9 \% & \mathbf{7 0 . 0} \% \\ 19.7 \% & 32.5 \% & 32.2 \% & \mathbf{2 1 . 4 \%} \\ & & & \\ 6.2 \% & 20.9 \% & 33.9 \% & \mathbf{8 . 6} \% \\ \mathbf{1 0 0 . 0 \%} & \mathbf{1 0 0 . 0 \%} & \mathbf{1 0 0 . 0 \%} & \mathbf{1 0 0 . 0 \%}\end{array}$


Tabel 2: Relatie tussen stedelijke gebieden en platteland - plattelandsgebieden

Aantal
1 Geen
plattelandsgebieden
2 Plattelandsgebieden
Totaal

$\begin{array}{rrr}1 & 2 & \text { Totaal } \\ & & \\ 1136181 & 24494 & \mathbf{1 1 6 0 6 7 5} \\ & & \\ 99660 & 51163 & \mathbf{1 5 0 8 2 3} \\ \mathbf{1 2 3 5 8 4 1} & \mathbf{7 5 6 5 7} & \mathbf{1 3 1 1 4 9 8}\end{array}$

Als $\%$ van pendel uit vertrekplaats

1 Geen

plattelandsgebieden

2 Plattelandsgebieden

Totaal

$\begin{array}{lrrr} & 1 & 2 & \text { Totaal } \\ 1 \text { Geen } & & & \\ \begin{array}{l}\text { plattelandsgebieden } \\ \text { Plattelandsgebieden }\end{array} & 97.9 \% & 2.1 \% & \mathbf{1 0 0 . 0 \%} \\ \quad \text { Totaal } & 66.1 \% & 33.9 \% & \mathbf{1 0 0 . 0 \%} \\ & \mathbf{9 4 . 2 \%} & \mathbf{5 . 8 \%} & \mathbf{1 0 0 . 0 \%}\end{array}$

\author{
gebieden
}

(1)

Als $\%$ van pendel naar plaats van bestemming

$\begin{array}{lrrr} & 1 & 2 & \text { Totaal } \\ 1 \text { Geen } & & & \\ \quad \begin{array}{l}\text { plattelandsgebieden } \\ \text { Plattelandsgebieden }\end{array} & 91.9 \% & 32.4 \% & \mathbf{8 8 . 5} \% \\ \quad \text { Totaal } & 8.1 \% & 67.6 \% & \mathbf{1 1 . 5 \%} \\ & \mathbf{1 0 0 . 0 \%} & \mathbf{1 0 0 . 0 \%} & \mathbf{1 0 0 . 0 \%}\end{array}$

\section{Plattelandsgebieden}

Aantal

1 Westhoek
2 Haspenhouw
3 Hageland
4 Meetjesland
Totaal
plattelandsregio's

\section{In eigen regio}

Buiten eigen regio

Totaal

Uitgaande Ingaande
pendel pendel pendel $\begin{gathered}\text { Ingaande } \\ \text { pendel }\end{gathered}$

$\begin{array}{rr}14778 & 15415 \\ 10806 & 24557 \\ 13657 & 44811 \\ 7056 & 19743 \\ \mathbf{4 6 2 9 7} & \mathbf{1 0 4 5 2 6}\end{array}$

6090

8420

9758

5092

29360
30193

$35363-19226$

$58468 \quad 23415$

$26799 \quad 12148$

$150823 \quad 75657$

\section{(1)}

1 Westhoek
2 Haspenhouw
3 Hageland
4 Meetjesland
Totaal
plattelandsregio's

$\begin{array}{llll}39.5 \% & -43.4 \% & 51.1 \% & 29.2 \% \\ 34.3 \% & -48.9 \% & 69.4 \% & 43.8 \% \\ 21.8 \% & -64.2 \% & 76.6 \% & 41.7 \% \\ 25.8 \% & -59.0 \% & 73.7 \% & 41.9 \% \\ \mathbf{2 8 . 1} \% & -\mathbf{5 6 . 1} \% & \mathbf{6 9 . 3} \% & \mathbf{3 8 . 8} \%\end{array}$

Legende:

(1) Relatie met rest van Vlaanderen + BHG: Ingaande pendel / uitgaande pendel 
De symbiose tussen plattelandsgebieden en stedelijke centra in Vlaanderen

(2) Relatie met rest van Vlaanderen: "Pendeldeficit" als \% van de totale pendelbewegingen met rest van Vlaanderen $+\mathrm{BHG}$

(3a) Pendel naar rest van Vlaanderen + BHG als \% van totale uitgaande pendel

(3b) Pendel vanuit rest van Vlaanderen $+\mathrm{BHG}$ als \% van totale ingaande pendel 


\section{Tabel 3: Pendelbewegingen binnen de plattelandsregio's}

\section{Aantal}

Economisc Andere Totaa
$\mathrm{h}$
knooppunt

1 Westhoek

2 Haspengouw

3 Hageland

4 Meetjesland

Totaa

plattelandsregio's

\begin{tabular}{|c|c|c|c|}
\hline $\begin{array}{l}\text { Econ. } \\
\text { Knoop. }\end{array}$ & 3804 & 2569 & 6373 \\
\hline Andere & 6820 & 1585 & 8405 \\
\hline Totaal & 10624 & 4154 & 14778 \\
\hline $\begin{array}{l}\text { Econ. } \\
\text { Knoop. }\end{array}$ & 1940 & 1602 & 3542 \\
\hline Andere & 5838 & 1426 & 7264 \\
\hline Totaal & 7778 & 3028 & 10806 \\
\hline $\begin{array}{l}\text { Econ. } \\
\text { Knoop. }\end{array}$ & 519 & 1604 & 2123 \\
\hline Andere & 7890 & 3644 & 11534 \\
\hline Totaal & 8409 & 5248 & 13657 \\
\hline $\begin{array}{l}\text { Econ. } \\
\text { Knoop. }\end{array}$ & 1642 & 1001 & 2643 \\
\hline Andere & 3148 & 1265 & 4413 \\
\hline Totaal & 4790 & 2266 & 7056 \\
\hline $\begin{array}{l}\text { Econ. } \\
\text { Knoop. }\end{array}$ & 7905 & 6776 & 14681 \\
\hline Andere & 23696 & 7920 & 31616 \\
\hline Totaal & 31601 & 14696 & 46297 \\
\hline
\end{tabular}

Als $\%$ van pendel uit vertrekplaats

Economisc Andere $\mathrm{h}$

knooppunt

\begin{tabular}{lll}
$59.7 \%$ & $40.3 \%$ & $100.0 \%$ \\
\hline $81.1 \%$ & $18.9 \%$ & $100.0 \%$ \\
$71.9 \%$ & $28.1 \%$ & $100.0 \%$ \\
\hline $54.8 \%$ & $45.2 \%$ & $100.0 \%$ \\
\hline $80.4 \%$ & $19.6 \%$ & $100.0 \%$ \\
$72.0 \%$ & $28.0 \%$ & $100.0 \%$ \\
& & \\
$24.4 \%$ & $75.6 \%$ & $100.0 \%$ \\
\hline $68.4 \%$ & $31.6 \%$ & $100.0 \%$ \\
$61.6 \%$ & $38.4 \%$ & $100.0 \%$ \\
\hline $62.1 \%$ & $37.9 \%$ & $100.0 \%$ \\
\hline $71.3 \%$ & $28.7 \%$ & $100.0 \%$ \\
$67.9 \%$ & $32.1 \%$ & $100.0 \%$ \\
& & \\
$53.8 \%$ & $46.2 \%$ & $100.0 \%$ \\
$74.9 \%$ & $25.1 \%$ & $100.0 \%$ \\
$68.3 \%$ & $31.7 \%$ & $100.0 \%$
\end{tabular}

Als \% van pendel naar plaats

van bestemming

Economisc Andere $\mathrm{h}$

knooppunt

$\begin{array}{rrr}35.8 \% & 61.8 \% & 43.1^{\prime} \\ 64.2 \% & 38.2 \% & 56.9^{\prime} \\ 100.0 \% & 100.0 \% & 100.0^{\prime} \\ 24.9 \% & 52.9 \% & 32.8^{\prime} \\ 75.1 \% & 47.1 \% & 67.2^{\prime} \\ 100.0 \% & 100.0 \% & 100.0^{\prime} \\ & & \\ 6.2 \% & 30.6 \% & 15.5^{\prime} \\ 93.8 \% & 69.4 \% & 84.5^{\prime} \\ 100.0 \% & 100.0 \% & 100.0^{\prime} \\ & & \\ 34.3 \% & 44.2 \% & 37.5 \\ 65.7 \% & 55.8 \% & 62.5^{\prime} \\ 100.0 \% & 100.0 \% & 100.0^{\prime} \\ & & \\ 25.0 \% & 46.1 \% & 31.7 \\ 75.0 \% & 53.9 \% & 68.3^{\prime} \\ 100.0 \% & 100.0 \% & 100.0^{\prime}\end{array}$


Figuur 1: Pendeltijd vanuit Westhoek dorpen naar dichstbijzijnde economische knooppunten

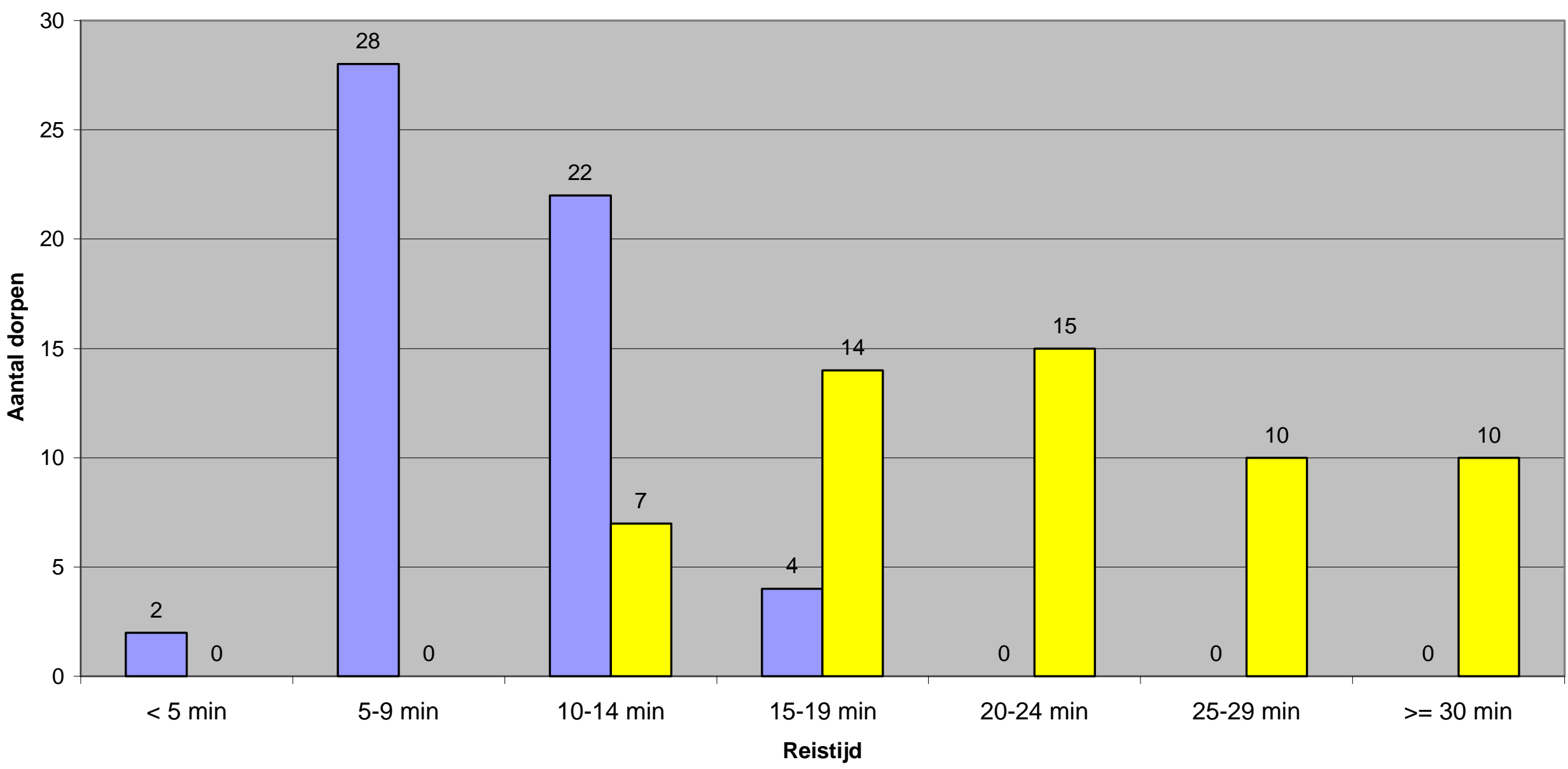

$\square$ Met econ. Knooppunten in Westhoek $\square$ Zonder econ. Knooppunten in Westhoek 
Tabel 4 : Werkende bevolking - Aantal vervoersmodus

\section{Gewogen gemiddelde}

\section{Stadsgewes}

Stadsgewest

Geen stadsgewest

$\begin{array}{rrrrrrrrr}1767104 & 5.58 \% & 1.96 \% & 7.53 \% & 53.71 \% & 7.69 \% & 0.26 \% & 9.30 \% & 4.90 \% \\ 532179 & 3.22 \% & 3.55 \% & 7.11 \% & 51.59 \% & 1.92 \% & 0.27 \% & 15.90 \% & 3.09 \% \\ & & & & & & & & \\ 1675448 & 4.98 \% & 2.00 \% & 7.28 \% & 52.11 \% & 7.77 \% & 0.25 \% & 10.35 \% & 5.14 \% \\ 454081 & 5.43 \% & 3.22 \% & 7.92 \% & 55.69 \% & 2.54 \% & 0.29 \% & 12.43 \% & 2.78 \% \\ 169754 & 4.51 \% & 3.19 \% & 7.72 \% & 57.60 \% & 2.57 \% & 0.32 \% & 11.23 \% & 2.51 \% \\ & & & & & & & & \\ 2100055 & 5.09 \% & 2.19 \% & 7.40 \% & 52.90 \% & 6.71 \% & 0.26 \% & 10.78 \% & 4.68 \% \\ 199228 & 4.51 \% & 3.82 \% & 7.86 \% & 56.66 \% & 2.55 \% & 0.29 \% & 11.29 \% & 2.39 \% \\ & & & & & & & & \\ 2043956 & 4.88 \% & 2.19 \% & 7.32 \% & 52.93 \% & 6.83 \% & 0.26 \% & 10.82 \% & 4.61 \% \\ 63342 & 3.06 \% & 2.34 \% & 7.24 \% & 51.28 \% & 1.85 \% & 0.35 \% & 17.13 \% & 4.60 \% \\ 66054 & 3.87 \% & 3.36 \% & 10.43 \% & 59.62 \% & 3.03 \% & 0.20 \% & 7.33 \% & 3.77 \% \\ 84216 & 11.15 \% & 3.96 \% & 8.58 \% & 56.01 \% & 2.61 \% & 0.18 \% & 6.41 \% & 2.97 \% \\ 41715 & 5.19 \% & 4.04 \% & 6.50 \% & 54.87 \% & 2.43 \% & 0.35 \% & 16.16 \% & 2.26 \%\end{array}$


De symbiose tussen plattelandsgebieden en stedelijke centra in Vlaanderen

Tabel 5 : Werkende bevolking - Aantal $<15 \mathrm{~min}<30 \mathrm{~min}<45 \mathrm{~min}>=60 \mathrm{~min}$ pendeltijd

\section{Gewogen gemiddelde}

\section{Stadsgewest}

Stadsgewest

Geen stadsgewest

$\begin{array}{rrrrr}1340590 & 21.58 \% & 56.89 \% & 81.12 \% & 10.35 \% \\ 396616 & 36.52 \% & 70.79 \% & 86.92 \% & 7.83 \% \\ & & & & \\ 1270319 & 24.47 \% & 59.45 \% & 82.34 \% & 9.58 \% \\ 343879 & 27.29 \% & 61.63 \% & 82.37 \% & 10.49 \% \\ 125008 & 24.20 \% & 62.18 \% & 83.79 \% & 9.74 \%\end{array}$

\section{Definitie Peter Cabus}

Stedelijk gebied

Agrarisch overgangsgebied

Agrarisch gebied

$125008 \quad 24.20 \%$

$62.18 \%$

$9.74 \%$

Bevolkingsdichtheid

Dichtbevolkt

$\begin{array}{rrrrr}1591761 & 24.92 \% & 59.97 \% & 82.48 \% & 9.68 \% \\ 147445 & 25.90 \% & 61.27 \% & 82.16 \% & 10.80 \%\end{array}$

Dunbevolkt

Plattelandsgebieden

Geen plattelandsgebied

Westhoek

$\begin{array}{rrrrr}1550369 & 24.81 \% & 60.04 \% & 82.65 \% & 9.47 \% \\ 43689 & 36.25 \% & 73.27 \% & 89.68 \% & 6.25 \% \\ 48711 & 27.89 \% & 64.82 \% & 85.41 \% & 9.78 \% \\ 64355 & 19.39 \% & 47.90 \% & 69.47 \% & 19.91 \% \\ 32082 & 26.19 \% & 61.22 \% & 84.43 \% & 9.19 \%\end{array}$

Haspengouw

Hageland

32082

$26.19 \%$

$61.22 \%$

$84.43 \%$

$9.19 \%$ 


$\begin{gathered}\text { Tabel } 6 \text { : Werkende bevolking - Aantal } \\ \text { afstand }\end{gathered} \quad<5 \mathrm{~km} \quad<10 \mathrm{~km} \quad<20 \mathrm{~km} \quad>=30 \mathrm{~km} \quad \begin{gathered}\text { Aantal } \\ \begin{array}{c}\text { Als } \% \\ \text { actieve } \\ \text { bevolking }\end{array}\end{gathered}$

\section{Gewogen gemiddelde}

\section{Stadsgewest}

Stadsgewest

Geen stadsgewest

\begin{tabular}{|c|c|c|c|c|c|c|}
\hline 1767104 & $23.30 \%$ & $43.38 \%$ & $73.58 \%$ & $13.99 \%$ & 1949753 & $9.37 \%$ \\
\hline 532179 & $30.84 \%$ & $47.87 \%$ & $74.11 \%$ & $14.35 \%$ & 611339 & $12.95 \%$ \\
\hline 1675448 & $26.57 \%$ & $47.12 \%$ & $74.46 \%$ & $13.12 \%$ & 1836385 & $8.76 \%$ \\
\hline 454081 & $22.19 \%$ & $38.50 \%$ & $71.85 \%$ & $16.87 \%$ & 517626 & $12.28 \%$ \\
\hline 169754 & $17.61 \%$ & $33.60 \%$ & $71.15 \%$ & $15.94 \%$ & 207081 & $18.25 \%$ \\
\hline 2100055 & $25.64 \%$ & $45.41 \%$ & $74.13 \%$ & $13.67 \%$ & 2323178 & $9.60 \%$ \\
\hline 199228 & $18.80 \%$ & $33.97 \%$ & $69.22 \%$ & $18.32 \%$ & 237914 & $16.26 \%$ \\
\hline 2043956 & $25.47 \%$ & $45.39 \%$ & $74.43 \%$ & $13.37 \%$ & 2264586 & $9.74 \%$ \\
\hline 63342 & $29.27 \%$ & $46.31 \%$ & $73.09 \%$ & $12.06 \%$ & 79310 & $20.13 \%$ \\
\hline 66054 & $21.06 \%$ & $36.82 \%$ & $71.12 \%$ & $16.72 \%$ & 74832 & $11.30 \%$ \\
\hline 84216 & $16.22 \%$ & $29.65 \%$ & $58.56 \%$ & $30.21 \%$ & 92705 & $9.16 \%$ \\
\hline 41715 & $21.80 \%$ & $36.12 \%$ & $73.81 \%$ & $15.03 \%$ & 49659 & $16.00 \%$ \\
\hline
\end{tabular}


Tabel 7 : Schoolgaande bevolking - vervoersmodus
Vervoer door de school
Auto als Auto als passagier bestuurder
Bus, tram, Motorfiets, Fiets, metro scooter bromfiets

Uitsluitend te voet

\section{Gewogen gemiddelde}

\section{Stadsgewest}

Stadsgewest

Geen stadsgewest

$\begin{array}{rrrrrrrrr}899789 & 4.39 \% & 5.47 \% & 21.39 \% & 2.95 \% & 15.68 \% & 0.08 \% & 22.29 \% & 17.45 \% \\ 286858 & 3.99 \% & 6.90 \% & 19.11 \% & 2.16 \% & 10.94 \% & 0.03 \% & 37.47 \% & 11.97 \% \\ & & & & & & & & \\ 853673 & 3.99 \% & 4.87 \% & 20.03 \% & 2.83 \% & 14.93 \% & 0.08 \% & 24.77 \% & 18.19 \% \\ 239493 & 5.22 \% & 7.52 \% & 23.01 \% & 2.70 \% & 12.53 \% & 0.05 \% & 30.87 \% & 10.52 \% \\ 93481 & 4.70 \% & 10.13 \% & 22.72 \% & 2.23 \% & 16.01 \% & 0.05 \% & 24.30 \% & 11.57 \% \\ & & & & & & & & \\ 1075763 & 4.30 \% & 5.44 \% & 20.72 \% & 2.81 \% & 14.74 \% & 0.72 \% & 25.67 \% & 16.77 \% \\ 110884 & 4.26 \% & 9.51 \% & 22.03 \% & 2.22 \% & 15.10 \% & 0.04 \% & 28.77 \% & 9.80 \% \\ & & & & & & & & 17 \% \\ 1052332 & 4.27 \% & 5.48 \% & 20.35 \% & 2.79 \% & 14.65 \% & 0.07 \% & 25.94 \% & 16.67 \% \\ 35849 & 5.02 \% & 8.64 \% & 19.07 \% & 1.18 \% & 11.67 \% & 0.03 \% & 27.14 \% & 17.10 \% \\ 35186 & 2.05 \% & 9.01 \% & 28.20 \% & 3.12 \% & 16.72 \% & 0.03 \% & 21.60 \% & 11.35 \% \\ 40059 & 4.95 \% & 9.33 \% & 29.00 \% & 3.02 \% & 13.25 \% & 0.08 \% & 23.50 \% & 9.15 \% \\ 23221 & 6.66 \% & 5.87 \% & 20.44 \% & 2.90 \% & 12.77 \% & 0.04 \% & 36.07 \% & 9.28 \%\end{array}$

\section{Definitie Peter Cabus}

Stedelijk gebied

Agrarisch overgangsgebied

Agrarisch gebied

Bevolkingsdichtheid

Dichtbevolkt

Dunbevolkt

\section{bebieden}

Geen plattelandsgebied

Westhoek

Haspengouw

Hageland

Meetjesland 
De symbiose tussen plattelandsgebieden en stedelijke centra in Vlaanderen

Tabel 8 : Schoolgaande bevolking - pendeltijd
Aantal $<15 \mathrm{~min}<30 \mathrm{~min}<45 \mathrm{~min}>=60 \mathrm{~min}$

\section{Gewogen gemiddelde}

Stadsgewest

Stadsgewest

Geen stadsgewest

\begin{tabular}{lllll}
899789 & $32.03 \%$ & $60.58 \%$ & $74.94 \%$ & $3.94 \%$ \\
\hline
\end{tabular}

Definitie Peter Cabus

Stedelijk gebied

Agrarisch overgangsgebied

Agrarisch gebied

286858

$37.10 \%$

$64.26 \% \quad 77.62 \%$

$3.58 \%$

$\begin{array}{rrrrr}853673 & 33.41 \% & 62.51 \% & 75.65 \% & 3.60 \% \\ 239493 & 33.91 \% & 60.32 \% & 76.01 \% & 4.35 \% \\ 93481 & 30.15 \% & 56.36 \% & 73.93 \% & 4.95 \%\end{array}$

Bevolkingsdichtheid

Dichtbevolkt

Dunbevolkt

$\begin{array}{lllll}1075763 & 33.48 \% & 61.97 \% & 75.78 \% & 3.76 \% \\ 110884 & 31.09 \% & 56.58 \% & 73.72 \% & 4.78 \%\end{array}$

$110884 \quad 31.09 \% \quad 56.58 \% \quad 73.72 \% \quad 4.78 \%$

\section{Plattelandsgebieden}

Geen plattelandsgebied

1052332

$33.15 \%$

$61.51 \%$

$75.52 \%$

$3.85 \%$

35849

$36.68 \%$

$61.72 \%$

$74.14 \%$

$3.84 \%$

Haspengouw

$35.33 \%$

$64.56 \%$

$78.57 \%$

$2.50 \%$

40059

$59.20 \%$

$75.56 \%$

$4.18 \%$

Meetjesland

23221

$34.68 \%$

$58.47 \%$

$76.56 \%$

$5.74 \%$ 
Tabel 9 : Schoolgaande bevolking - afstand

\section{Gewogen gemiddelde}

\section{Stadsgewest}

Stadsgewest

Geen stadsgewest

\section{Definitie Peter Cabus}

Stedelijk gebied

Agrarisch overgangsgebied Agrarisch gebied

\section{Bevolkingsdichtheid}

Dichtbevolkt

Dunbevolkt

Plattelandsgebieden

Geen plattelandsgebied

Westhoek

Haspengouw

Hageland

Meetjesland

$$
\text { Aantal } \quad<5 \mathrm{~km} \quad<10 \mathrm{~km} \quad<20 \mathrm{~km} \quad>=30 \mathrm{~km}
$$

$49.86 \% \quad 67.56 \% \quad 80.60 \% \quad 3.10 \%$

$53.16 \% \quad 69.85 \% \quad 82.12 \% \quad 4.25 \%$

$\begin{array}{rrrrr}853673 & 53.09 \% & 70.48 \% & 81.09 \% & 3.09 \% \\ 239493 & 46.04 \% & 63.73 \% & 81.16 \% & 3.93 \% \\ 93481 & 40.25 \% & 57.73 \% & 79.35 \% & 4.60 \%\end{array}$

$1075763 \quad 51.59 \% \quad 69.10 \% \quad 81.22 \% \quad 3.24 \%$

$110884 \quad 41.62 \% \quad 58.57 \% \quad 78.52 \% \quad 4.72 \%$

$\begin{array}{rrrrr}1052332 & 51.19 \% & 68.65 \% & 81.11 \% & 3.28 \% \\ 35849 & 50.91 \% & 66.21 \% & 78.79 \% & 4.64 \% \\ 35186 & 47.43 \% & 65.76 \% & 81.80 \% & 2.84 \% \\ 40059 & 41.78 \% & 62.33 \% & 79.96 \% & 4.91 \% \\ 23221 & 45.99 \% & 60.58 \% & 78.37 \% & 4.17 \%\end{array}$


Tabel 10: "Jobbereik" van dorpen in de Westhoek

\begin{tabular}{|c|c|c|c|c|}
\hline $\begin{array}{l}\text { Dorp } \\
\text { Bovekerk }\end{array}$ & $\begin{array}{c}\text { Relatief } \\
\text { Totaal } \\
\mathbf{1 9 8 1} \\
100.0 \%\end{array}$ & $\begin{array}{c}\text { Relatief } \\
\text { totaal } \\
\mathbf{1 9 9 6} \\
100.0 \%\end{array}$ & $\begin{array}{c}\text { Relatieve } \\
\text { Groei } \\
92-96 \\
76.1 \%\end{array}$ & $\begin{array}{c}\text { Relatieve } \\
\text { Groei } \\
\mathbf{8 1 - 9 6} \\
100.0 \%\end{array}$ \\
\hline 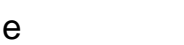 & & & & \\
\hline Boezinge & $84.2 \%$ & $83.8 \%$ & $81.3 \%$ & $93.6 \%$ \\
\hline Zande & $83.2 \%$ & $83.6 \%$ & $60.4 \%$ & $81.1 \%$ \\
\hline lerken & $80.2 \%$ & $80.1 \%$ & $71.3 \%$ & $87.2 \%$ \\
\hline Illebeke & $79.4 \%$ & $78.1 \%$ & $79.6 \%$ & $90.5 \%$ \\
\hline loesten & $76.2 \%$ & $77.7 \%$ & $76.3 \%$ & $90.9 \%$ \\
\hline $\begin{array}{l}\text { Zuidschot } \\
\text { e }\end{array}$ & $76.8 \%$ & $77.7 \%$ & $100.0 \%$ & $97.1 \%$ \\
\hline ielen & $74.9 \%$ & $75.2 \%$ & $89.4 \%$ & $98.2 \%$ \\
\hline kschote & $74.7 \%$ & $75.1 \%$ & $92.8 \%$ & $88.2 \%$ \\
\hline eerst & $68.4 \%$ & $68.5 \%$ & $55.6 \%$ & $65.9 \%$ \\
\hline ostkerke & $66.3 \%$ & $67.2 \%$ & $58.8 \%$ & $69.5 \%$ \\
\hline eiem & $65.4 \%$ & $66.2 \%$ & $55.0 \%$ & $67.7 \%$ \\
\hline $\begin{array}{l}\text { Oostvleter } \\
\text { en }\end{array}$ & $63.9 \%$ & $64.8 \%$ & $55.2 \%$ & $69.6 \%$ \\
\hline $\begin{array}{l}\text { St. } \\
\text { Jacobskap } \\
\text { elle }\end{array}$ & $64.6 \%$ & $64.3 \%$ & $56.9 \%$ & $66.3 \%$ \\
\hline $\begin{array}{l}\text { Westvlete } \\
\text { ren }\end{array}$ & $60.9 \%$ & $62.0 \%$ & $56.7 \%$ & $67.8 \%$ \\
\hline Hollebeke & $59.3 \%$ & $59.3 \%$ & $75.0 \%$ & $75.5 \%$ \\
\hline Dikkebus & $58.7 \%$ & $58.7 \%$ & $4.3 \%$ & $74.5 \%$ \\
\hline $\begin{array}{l}\text { Voormeze } \\
\text { le }\end{array}$ & $58.6 \%$ & $58.5 \%$ & $73.9 \%$ & $74.4 \%$ \\
\hline Pervijze & $56.7 \%$ & $57.6 \%$ & $40.8 \%$ & $56.5 \%$ \\
\hline $\begin{array}{l}\text { Stuiveken } \\
\text { skerke }\end{array}$ & $55.6 \%$ & $56.5 \%$ & $40.5 \%$ & $55.2 \%$ \\
\hline $\begin{array}{l}\text { Nieuwkap } \\
\text { elle }\end{array}$ & $55.1 \%$ & $55.6 \%$ & $47.5 \%$ & $59.3 \%$ \\
\hline Leke & $54.2 \%$ & $55.3 \%$ & $36.2 \%$ & $54.1 \%$ \\
\hline $\begin{array}{l}\text { Ramskap } \\
\text { elle }\end{array}$ & $54.5 \%$ & $54.7 \%$ & $35.0 \%$ & $49.4 \%$ \\
\hline $\begin{array}{l}\text { Lampernis } \\
\text { se }\end{array}$ & $51.8 \%$ & $52.3 \%$ & $41.9 \%$ & $54.6 \%$ \\
\hline $\begin{array}{l}\text { Noordsch } \\
\text { ote }\end{array}$ & $47.0 \%$ & $48.0 \%$ & $47.8 \%$ & $56.7 \%$ \\
\hline Mesen & $46.2 \%$ & $46.7 \%$ & 39. & $57.1 \%$ \\
\hline Wulpe & $45.2 \%$ & $46.5 \%$ & $26.2 \%$ & $41.0 \%$ \\
\hline $\begin{array}{l}\text { Avekapell } \\
\mathrm{e}\end{array}$ & $41.6 \%$ & $44.0 \%$ & $29.5 \%$ & $42.9 \%$ \\
\hline Renir & $42.4 \%$ & $\%$ & 38 & $49.5 \%$ \\
\hline $\begin{array}{l}\text { Hoogstad } \\
\text { e }\end{array}$ & $42.9 \%$ & $42.7 \%$ & $37.1 \%$ & $43.5 \%$ \\
\hline $\begin{array}{l}\text { Booitshoe } \\
\text { ke }\end{array}$ & $38.3 \%$ & $40.6 \%$ & $22.9 \%$ & $37.7 \%$ \\
\hline $\begin{array}{l}\text { Beauvoor } \\
\text { de }\end{array}$ & $38.3 \%$ & $40.6 \%$ & $22.5 \%$ & $37.6 \%$ \\
\hline $\begin{array}{l}\text { Gijverinkh } \\
\text { ove }\end{array}$ & $40.0 \%$ & $40.3 \%$ & $42.7 \%$ & $44.1 \%$ \\
\hline $\begin{array}{l}\text { Alveringe } \\
\mathrm{m}\end{array}$ & $38.7 \%$ & $39.2 \%$ & $35.0 \%$ & $43.1 \%$ \\
\hline Reningelst & $38.9 \%$ & $39.0 \%$ & $35.9 \%$ & $47.7 \%$ \\
\hline
\end{tabular}


De symbiose tussen plattelandsgebieden en stedelijke centra in Vlaanderen

\begin{tabular}{lllll}
\hline Lo & $38.0 \%$ & $38.7 \%$ & $40.4 \%$ & $43.4 \%$ \\
Pollinkhov & $38.2 \%$ & $38.4 \%$ & $33.0 \%$ & $39.5 \%$ \\
e & & & & \\
Wijtschate & $38.0 \%$ & $38.4 \%$ & $33.8 \%$ & $48.0 \%$ \\
Steenkerk & $36.2 \%$ & $38.3 \%$ & $22.2 \%$ & $34.6 \%$ \\
e & & & & \\
Eggewaart & $35.8 \%$ & $37.9 \%$ & $20.6 \%$ & $33.3 \%$ \\
skapelle & & & & \\
Krombeke & $37.2 \%$ & $37.8 \%$ & $36.5 \%$ & $42.2 \%$ \\
Bulskamp & $35.2 \%$ & $37.4 \%$ & $19.8 \%$ & $33.2 \%$ \\
De Klijte & $36.8 \%$ & $37.2 \%$ & $35.4 \%$ & $47.0 \%$ \\
Kemmel & $35.9 \%$ & $36.3 \%$ & $33.9 \%$ & $46.0 \%$ \\
Izenberge & $35.6 \%$ & $36.0 \%$ & $30.1 \%$ & $38.7 \%$ \\
Wulverge & $34.4 \%$ & $34.4 \%$ & $31.7 \%$ & $41.0 \%$ \\
m & & & & \\
Roesbrug & $33.4 \%$ & $34.3 \%$ & $40.0 \%$ & $40.9 \%$ \\
ge- & & & & \\
Haringe & & & & \\
Proven & $33.7 \%$ & $33.7 \%$ & $38.8 \%$ & $41.5 \%$ \\
Dranouter & $32.2 \%$ & $31.9 \%$ & $35.9 \%$ & $37.8 \%$ \\
Leisele & $30.9 \%$ & $31.6 \%$ & $26.0 \%$ & $34.2 \%$ \\
Westouter & $31.7 \%$ & $31.5 \%$ & $32.9 \%$ & $37.1 \%$ \\
Nieuwkerk & $31.8 \%$ & $31.4 \%$ & $34.7 \%$ & $36.5 \%$ \\
e & & & & \\
Watou & $30.1 \%$ & $30.0 \%$ & $34.3 \%$ & $35.9 \%$ \\
Beveren & $27.2 \%$ & $28.5 \%$ & $27.4 \%$ & $34.3 \%$ \\
Loker & $28.5 \%$ & $28.2 \%$ & $30.2 \%$ & $32.4 \%$ \\
Houtem & $24.7 \%$ & $25.4 \%$ & $21.6 \%$ & $28.7 \%$
\end{tabular}


Tabel 12: Intermediaire vraag tussen drie gebiedstypes

\begin{tabular}{|c|c|c|c|c|}
\hline Aantal jobs & 1 & 2 & 3 & Totaal \\
\hline 1 Agrarisch gebied & 1318 & 3931 & 14889 & 20138 \\
\hline 2 Agrarisch overgangsgbied & 3665 & 11591 & 46672 & 61928 \\
\hline 3 Stedelijk gebied & 11936 & 41734 & 190305 & 243975 \\
\hline Totaal & 16919 & 57256 & 251866 & 326041 \\
\hline Rijpercentages & 1 & 2 & 3 & Totaal \\
\hline 1 Agrarisch gebied & $6.5 \%$ & $19.5 \%$ & $73.9 \%$ & $100.0 \%$ \\
\hline 2 Agrarisch overgangsgbied & $5.9 \%$ & $18.7 \%$ & $75.4 \%$ & $100.0 \%$ \\
\hline 3 Stedelijk gebied & $4.9 \%$ & $17.1 \%$ & $78.0 \%$ & $100.0 \%$ \\
\hline Kolompercentages & 1 & 2 & 3 & \\
\hline 1 Agrarisch gebied & $7.8 \%$ & $6.9 \%$ & $5.9 \%$ & \\
\hline 2 Agrarisch overgangsgbied & $21.7 \%$ & $20.2 \%$ & $18.5 \%$ & \\
\hline 3 Stedelijk gebied & $70.5 \%$ & $72.9 \%$ & $75.6 \%$ & \\
\hline Totaal & $100.0 \%$ & $100.0 \%$ & $100.0 \%$ & \\
\hline
\end{tabular}




\section{Tabel 13: Totaal van de vraag en middelen voor drie}

\section{gebiedstypes}

\section{Aantal jobs}

1 Agrarisch gebied

2 Agrarisch overgangsgbied

3 Stedelijk gebied

Totaal intermediaire vraag

Bruto toegevoegde waarde

Import

Totaal

\section{Rijpercentages}

1 Agrarisch gebied

2 Agrarisch overgangsgbied

3 Stedelijk gebied

Totaal intermediaire vraag

\section{Kolompercentages}

1 Agrarisch gebied

2 Agrarisch overgangsgbied

3 Stedelijk gebied

Totaal intermediaire productie

Bruto toegevoegde waarde

Import

Totaal

Intermediaire vraag

1

2

$\begin{array}{rr}1318 & 3931 \\ 3665 & 11591 \\ 11936 & 41734 \\ 16919 & 57256 \\ 55177 & 185678 \\ 21349 & 60265 \\ 93445 & 303199\end{array}$

Intermediaire vraag

1

2

\section{$1.4 \%$}

$1.2 \%$

$0.8 \%$

$0.9 \%$

$1.4 \%$

$3.9 \%$

$12.8 \%$

$18.1 \%$

$59.0 \%$

$22.8 \%$

$100.0 \%$

Noot: *: Export $=1,093255 \mathrm{x}$ import
14889

46672

190305

251866

944810

233963

1430639

Finale vraag

Totaal

$20138 \quad 3248$

$61928 \quad 10348$

$243975 \quad 45613$

$326041 \quad 60000$

1185665

315577

1827283

Finale vraag

3

2

$21.6 \% \quad 3.5 \%$

$20.4 \% \quad 3.4 \%$

$17.1 \% \quad 3.2 \%$

$17.8 \% \quad 3.3 \%$

$10.4 \%$

$10.8 \%$

$11.1 \%$

$11.1 \%$

$13.8 \%$

Totaal

$1.1 \%$

$3.4 \%$

$13.4 \%$

$17.8 \%$

$64.9 \%$

$17.3 \%$

$100.0 \%$ 